\title{
NO Chemisorption on Cu/SSZ-13: A Comparative Study from Infrared Spectroscopy and DFT Calculations
}

\author{
Renqin Zhang, ${ }^{\dagger}$ Jean-Sabin McEwen, ${ }^{* \dagger, \ddagger, \S}$ Márton Kollár, "Feng Gao," Yilin Wang," János Szanyi," \\ and Charles H.F. Peden*,ll \\ ${ }^{\dagger}$ The Gene and Linda Voiland School of Chemical Engineering and Bioengineering, Washington State University, Pullman, \\ Washington 99164, United States \\ ${ }^{\ddagger}$ Department of Physics and Astronomy, Washington State University, Pullman, Washington 99164, United States \\ ${ }^{\S}$ Department of Chemistry, Washington State University, Pullman, Washington 99164, United States \\ "Institute for Integrated Catalysis, Pacific Northwest National Laboratory, Richland, Washington 99352, United States
}

\section{Supporting Information}

ABSTRACT: The locations and energies of $\mathrm{Cu}$ ions in a Cu/SSZ-13 zeolite catalyst were investigated by density functional theory (DFT) calculations. For "naked" $\mathrm{Cu}^{2+}$ ions (i.e., $\mathrm{Cu}^{2+}$ ions with no ligands in their coordination spheres other than zeolite lattice oxygen atoms), the more energetically favorable sites are within a 6-membered ring. However, with the presence of various adsorbates, the energy difference between 6- and 8-membered ring locations greatly diminishes. Specifically, $\mathrm{Cu}^{2+}$ ions are substantially stabilized by $-\mathrm{OH}$ ligands $\left(\right.$ as $\left.\left[\mathrm{Cu}^{\mathrm{II}}(\mathrm{OH})\right]^{+}\right)$, making the extra-framework sites in an 8-membered ring energetically more favorable than 6-membered ring sites. Under fully dehydrated high vacuum conditions with different $\mathrm{Si} / \mathrm{Al}$ and $\mathrm{Cu} / \mathrm{Al}$ ratios, three chemisorbed $\mathrm{NO}$ species coexist upon exposure of $\mathrm{NO}$ to $\mathrm{Cu} / \mathrm{SSZ}-13$ : $\mathrm{NO}^{+}, \mathrm{Cu}^{2+}-\mathrm{NO}$, and $\mathrm{Cu}^{+}-\mathrm{NO}$. The relative signal intensities for these bands vary greatly with $\mathrm{Si} / \mathrm{Al}$ ratios. The vibrational frequency of chemisorbed $\mathrm{NO}$ was found to be very sensitive to the location of $\mathrm{Cu}^{2+}$ ions. On the one hand, with the aid from DFT calculations, the nature for these vibrations can be assigned in detail. On the other hand, the relative intensities for various $\mathrm{Cu}^{2+}-\mathrm{NO}$ species provide a good measure of the nature of $\mathrm{Cu}^{2+}$ ions as functions of $\mathrm{Si} / \mathrm{Al}$ and $\mathrm{Cu} / \mathrm{Al}$ ratios and the presence of humidity. These new findings cast doubt on the generally accepted proposal that only $\mathrm{Cu}^{2+}$ ions located in 6-membered rings are catalytically active for $\mathrm{NH}_{3}-\mathrm{SCR}$.

KEYWORDS: infrared spectroscopy, DFT, NO chemisorption, oxidation state, Cu/SSZ-13, dehydration, Brønsted acid site

\section{INTRODUCTION}

In the past few years, small-pore copper-ion-exchanged zeolite catalysts $(\mathrm{Cu} / \mathrm{SSZ}-13)$ with a chabazite $(\mathrm{CHA})$ structure have been commercialized as part of the emission control systems for diesel passenger vehicles and light-, medium-, and heavyduty trucks in the U.S. and Europe, due to their remarkable activity and hydrothermal stability for the $\mathrm{NH}_{3}$ selective catalytic reduction (SCR) process. $^{1-4}$ Along with studies aimed at assessing the properties of the $\mathrm{Cu} / \mathrm{SSZ}-13$ catalysts under practical engine exhaust operating conditions, considerable recent research has also focused on the fundamental chemical and physical properties of this interesting catalytic material.

Initial reports suggested that $\mathrm{Cu}$ ions are located only in the 6-membered rings of the primary double 6-membered ring structures of this CHA zeolite. ${ }^{5-7}$ However, recent studies have revealed that $\mathrm{Cu}$ ions can occupy more than one ion-exchange site. The results of $\mathrm{H}_{2}$ temperature-programmed reduction, zeolite framework $\mathrm{T}-\mathrm{O}-\mathrm{T}$ vibrations, and electron paramagnetic resonance (EPR) experiments during dehydration also suggested facile movement of copper ions in the presence of strongly interacting adsorbates (e.g., $\left.\mathrm{H}_{2} \mathrm{O}\right){ }^{8-10} \mathrm{~A}$ recent in operando X-ray absorption spectroscopy (XAS) studied by Riberio and co-workers has concluded that the "standard" (i.e., $\left.\mathrm{NO}_{x}=\mathrm{NO}\right) \mathrm{NH}_{3}$ SCR reaction proceeds via a redox mechanism between $\mathrm{Cu}^{2+}$ and $\mathrm{Cu}^{+}$oxidation states. ${ }^{11,12}$ This conclusion was drawn because under "fast" and " $\mathrm{NO}_{2}$ " SCR conditions, in which $\mathrm{NO}_{2}$ is half or all of the $\mathrm{NO}_{x}$ feed, respectively, $\mathrm{Cu}^{2+}$ remains as the only evident $\mathrm{Cu}$ oxidation state. Under the more reducing "standard" SCR conditions, where there is no $\mathrm{NO}_{2}$ in the feed, a $\mathrm{Cu}^{+}$species is evident in the XAS data. ${ }^{12}$ In line with such a redox mechanism, $\mathrm{Cu}^{2+}$ can, in principle, be reduced to $\mathrm{Cu}^{+}$by either $\mathrm{NH}_{3}$ or $\mathrm{NO}$, and $\mathrm{Cu}^{+}$ can then be oxidized by $\mathrm{O}_{2}$ to $\mathrm{Cu}^{2+}$ to finish the redox cycling. In our recent FTIR and NMR spectroscopic study of NO and $\mathrm{Cu} / \mathrm{SSZ}-13$ interactions, we suggested that $\mathrm{Cu}^{2+}$ can be reduced to $\mathrm{Cu}^{+}$by $\mathrm{NO}$, leading to the formation of the spectroscopically observed $\mathrm{Cu}-$ nitrosyl complex $\left(\mathrm{Cu}^{+}-\right.$ $\left.\mathrm{NO}^{+}\right) .{ }^{3,13,14}$ Based on the spectroscopic evidence, a "standard"

\footnotetext{
Received: April 25, 2014
}

Revised: September 9, 2014 

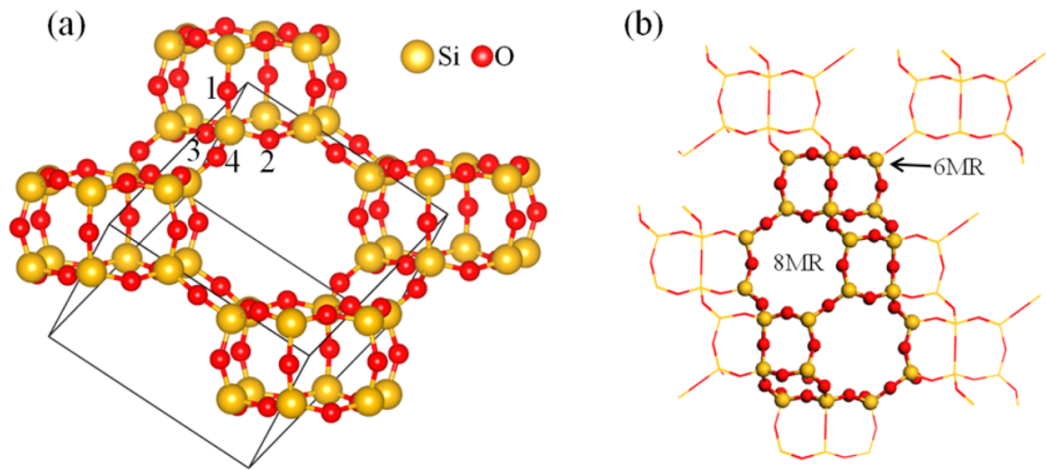

Figure 1. (a) Structure of a pure SSZ-13 zeolite belonging to the chabazite zeolite family, in which the rhombohedral unit cell used in our calculations is shown. The rhombohedral unit cell contains $12 \mathrm{Si}$ and $24 \mathrm{O}$ atoms. There are four nonequivalent $\mathrm{O}$ sites, which are labeled by numbers 1-4; their differences are described in the main text. (b) Another view of the chabazite structure (see ref 4). Large yellow and small red balls represent $\mathrm{Si}$ and $\mathrm{O}$ atoms, respectively.

SCR mechanism that involves such a $\mathrm{Cu}-$ nitrosyl complex has been proposed. 3 .13

The first application of density functional theory (DFT) methods to the modeling of $\mathrm{NO}_{x}$ catalysis on $\mathrm{Cu}$ zeolites was done with single- and multi-T-site cluster models. ${ }^{15-18}$ These computational results are helpful for understanding the catalytic activity and reaction mechanism(s) on $\mathrm{Cu}$-exchanged zeolites. For example, for the decomposition of $\mathrm{NO}$ on $\mathrm{Cu}$-exchanged zeolites, ${ }^{16}$ it was found that there is evidence for a pathway involving two successive $\mathrm{O}$ atom transfers to an isolated, zeolite-bound $\mathrm{Cu}^{+}$center, initiated by the formation of a shortlived and difficult to detect isonitrosyl intermediate, and yielding sequentially $\mathrm{N}_{2} \mathrm{O}$ and $\mathrm{Cu}$-bound $\mathrm{O}$ followed by $\mathrm{N}_{2}$ and $\mathrm{Cu}$-bound $\mathrm{O}_{2}$. Such models have been shown to be generally in good agreement with fully periodic models, although interactions, in particular with $\mathrm{H}_{2} \mathrm{O}$, and more extended portions of the lattice are only fully captured with periodic models. ${ }^{12}$ Such periodic models have been actively used to study the SSZ-13 zeolite. ${ }^{4,12,19-25}$ Göltl et al. predicted a distribution of active sites at different levels of ion exchange by considering the energetic variations of the $\mathrm{Cu}$ locations in $\mathrm{Cu} / \mathrm{SSZ}-13 .^{24}$ Although an isolated $\mathrm{Cu}^{2+}$ ion in $\mathrm{Cu} / \mathrm{SSZ}-13$ has been suggested to be an active site under SCR conditions, ${ }^{7}$ further studies suggested that the nature of the $\mathrm{Cu}$ species in $\mathrm{Cu} / \mathrm{SSZ}-13$ is dependent on the $\mathrm{Si} / \mathrm{Al}$ and $\mathrm{Cu} / \mathrm{Al}$ atomic ratios. $^{22,23}$ With the aid of periodic DFT calculations, it was found that for a series of $\mathrm{Si} / \mathrm{Al}=4.5$ samples with various $\mathrm{Cu}$ loadings, the dominant $\mathrm{Cu}$ ion configuration is an isolated $\mathrm{Cu}^{2+}$ ion in $\mathrm{Cu} / \mathrm{SSZ}-13$ with a $\mathrm{Cu} / \mathrm{Al}$ atomic ratio below 0.2 , while $\mathrm{Cu}_{x} \mathrm{O}_{y}$ species in the 8-membered ring of $\mathrm{Cu} / \mathrm{SSZ}-13$ also form when the $\mathrm{Cu} / \mathrm{Al}$ ratio is above $0.2{ }^{23}$ However, only the isolated $\mathrm{Cu}^{2+}$ ions were claimed to be the SCR active centers while $\mathrm{Cu}_{x} \mathrm{O}_{y}$ species were suggested to be inert. This conclusion is somewhat surprising because prior studies on other $\mathrm{Cu} /$ zeolite SCR catalysts $(\mathrm{Cu} / \mathrm{ZSM}-5, \mathrm{Cu} /$ beta, $\mathrm{Cu} / \mathrm{Y}$, etc.) seem to agree in general that a $\mathrm{Cu}$-ion dimer species is a particularly SCR active species. ${ }^{3}$ To date, there does not seem to be convincing evidence, either experimentally or theoretically, that explains why $\mathrm{Cu} / \mathrm{SSZ}-13$ has to be different from other Cu-zeolites. In our most recent studies on SCR kinetics, we discovered that, at low $\mathrm{Cu}$ loadings where $\mathrm{Cu}$-dimer species are not spectroscopically detected, our kinetic data indicate that transient dimers can indeed form and act as reaction centers under typical low temperature $\mathrm{NH}_{3}-\mathrm{SCR}$ reaction conditions. ${ }^{9}$
As part of our continuing research efforts aimed at understanding detailed SCR mechanisms and metal/zeolite structure-function relationships from both experimental and theoretical approaches, in the present study, we investigate NO chemisorption on $\mathrm{Cu} / \mathrm{SSZ}-13$ using both FTIR spectroscopy and DFT calculations. These recent studies have provided new insights into the nature of isolated $\mathrm{Cu}$ ion species as functions of the $\mathrm{Si} / \mathrm{Al}$ ratio, $\mathrm{Cu}$ loading, and the presence or absence of ligands attaching to the catalytically active centers.

\section{METHODS}

2.1. Computational Details. DFT calculations were performed with the Vienna Ab-initio Simulation Package (VASP) code. ${ }^{26,27}$ The projector augmented-wave (PAW) ${ }^{28,29}$ method and the generalized-gradient approximation (GGA), using the PW91 functional, ${ }^{30}$ were employed for the treatment of the electron-ion interactions and the exchange-correlation effects, respectively. With its PAW potentials, VASP combines the accuracy of all-electron methods with the computational efficiency of plane-wave approaches. The total energy convergence threshold was set to $10^{-8} \mathrm{eV}$, and the geometries were considered to be fully relaxed when the forces were less than $0.01 \mathrm{eV} / \AA ̊$. A $400 \mathrm{eV}$ plane-wave cutoff and a single $\Gamma$ point sampling of the Brillouin zone were used for these calculations. In order to obtain an accurate density of states (DOS) for $\mathrm{Cu}$, higher Monkhorst-Pack k-point grids of $(5 \times 5$ $\times 5)$ were used. The default values of RWIGS for the PW91 pseudopotential were employed in our DOS calculations. The numbers of valence electrons are 4, 6, 3, and 11 for $\mathrm{Si}, \mathrm{O}, \mathrm{Al}$ and $\mathrm{Cu}$ atoms, respectively.

As is well-known, the SSZ-13 zeolite belongs to the CHA zeolite family, with a structure that is composed of 4-membered rings (4MR), 6-membered rings (6MR), and 8-membered rings (8MR), as displayed in Figure 1a. There are two equivalent ways to construct the CHA unit cell. One is the hexagonal cell with 36 symmetry-equivalent tetrahedral $(\mathrm{T})$ sites and $72 \mathrm{O}$ atoms. The other is a rhombohedral cell containing $12 \mathrm{~T}$ sites and $24 \mathrm{O}$ atoms. All $\mathrm{T}$ sites are crystallographically equivalent and there are four nonequivalent $\mathrm{O}$ sites, which can be distinguished according to their participation in the different ring structures of the framework. As shown in Figure 1a, the oxygen $\mathrm{O} 1$ belongs to two $4 \mathrm{MRs}$ and one $8 \mathrm{MR}$ (abbreviated as $(4,4,8))$; O2 belongs to $(4,6,8)$; O3 belongs to $(4,4,6)$; and finally $\mathrm{O} 4$ belongs to $(4,8,8)$. The rhombohedral unit cell was used in all of our calculations, as shown in Figure 1. 
In a rhombohedral unit cell, electron deficits are generated upon replacement of $\mathrm{Si}$ atoms by $\mathrm{Al}$ atoms. Extra framework $\mathrm{Cu}$ ions are then required to compensate such electron deficits. For a one-electron deficit, a $\mathrm{Cu}^{+}$ion is required. In this case, the resulting zeolite configuration is denoted as $\mathrm{ZCu}$. A twoelectron deficit is compensated by a $\mathrm{Cu}^{2+}$ ion, and this configuration is labeled as $\mathrm{Z}_{2} \mathrm{Cu}$. Alternatively, a two-electron deficit can be compensated for with a Brønsted acid site $\left(\mathrm{H}^{+}\right)$ and $\mathrm{a} \mathrm{Cu}^{+}$ion. The resulting configuration is labeled as $\mathrm{HZ}_{2} \mathrm{Cu}$. After full relaxation of the rhombohedral unit cell, the calculated equilibrium volumes of $\mathrm{ZCu}, \mathrm{Z}_{2} \mathrm{Cu}$, and $\mathrm{HZ}_{2} \mathrm{Cu}$ are the same at $823.6 \AA^{3}$. Detailed calculations and plots of energy as a function of volume can be found in the Supporting Information (Figure S1). As will be shown below, besides "naked" $\mathrm{Cu}$ ions, $\mathrm{Cu}$ ions with ligands (e.g., $[\mathrm{Cu}(\mathrm{OH})]^{+}$ species) as charge balancing moieties are also considered in this study.

For the molecular adsorption calculations, the unit cells with chemisorbed $\mathrm{NO}$ were fully relaxed to get their equilibrium volumes, which are $823.6,828.8$, and $834.1 \AA^{3}$, respectively, for $\mathrm{ZCu}, \mathrm{Z}_{2} \mathrm{Cu}$, and $\mathrm{HZ}_{2} \mathrm{Cu}$. The energy plots as a function of volume for the NO-adsorbed systems are shown in Figure $\mathrm{S} 1$ of the Supporting Information. The adsorption of NO has no effect on the equilibrium volume of $\mathrm{ZCu}$, but it causes a slight increase of the equilibrium volumes for $\mathrm{Z}_{2} \mathrm{Cu}$ and $\mathrm{HZ}_{2} \mathrm{Cu}$. We note, under the experimental conditions used here, that not all $\mathrm{Cu}$ sites will be occupied by NO molecules, and additionally, not every unit cell will contain a $\mathrm{Cu}$ atom. Because of this, there will be local strain on the unit cell which, due to its complexity, cannot be addressed in our calculations. In studying other adsorbates, unit cell lattice constants identified for the NOadsorbed systems were used. Adsorption energies $E_{\text {ads }}$ are calculated by the following equation:

$$
E_{\text {ads }}=E_{\text {tot }}-E_{\text {zeolite }}-E_{\mathrm{M}}
$$

where $E_{\text {tot }}, E_{\text {zeolite, }}$ and $E_{\mathrm{M}}$ are the total energies of the zeolite system in the presence of molecular species, the clean zeolite system, and the isolated molecules in the gas phase, respectively.

2.2. Experimental Section. Three SSZ-13 zeolite substrates with $\mathrm{Si} / \mathrm{Al}$ ratios of 6,12 , and 35 were used in this study. The sample with $\mathrm{Si} / \mathrm{Al}=6$ was synthesized in-house following the procedure described by Fickel and Lobo. ${ }^{5}$ The high $\mathrm{Si} / \mathrm{Al}$ samples (12 and 35) were also synthesized in-house, using procedures described by Deka et al. ${ }^{7} \mathrm{Cu} / \mathrm{SSZ}-13$ catalysts with various $\mathrm{Cu} / \mathrm{Al}$ ratios were then prepared using traditional solution ion-exchange methods that have also been described previously. ${ }^{31}$ Prior to ion exchange with a $\mathrm{CuSO}_{4}$ solution, the as-synthesized $\mathrm{Na} / \mathrm{SSZ}-13$ samples were first exchanged to $\mathrm{NH}_{4} /$ SSZ-13. $\mathrm{Si}, \mathrm{Al}$ and $\mathrm{Cu}$ contents were determined by elemental analysis (ICP), while the crystallinity of the zeolites was confirmed by XRD.

In situ static transmission IR experiments were conducted in a home-built cell (described in detail previously ${ }^{32}$ ) housed in the sample compartment of a Bruker Vertex 80 spectrometer. In short, powder samples were pressed onto a tungsten mesh that can be resistively heated (by passing current through the metal grid) or cooled with liquid nitrogen. Unless otherwise specified, samples were annealed in vacuum $\left(\sim 1 \times 10^{-7}\right.$ Torr $)$ at $500{ }^{\circ} \mathrm{C}$ for $2 \mathrm{~h}$ and cooled back to ambient temperature prior to background spectra acquisition. Then $\mathrm{NO}$ was introduced into the cell in a pulse mode fashion $(\sim 0.005$ Torr for the first pulse, until total pressure in the IR cell reached $\sim 0.5$ Torr).
After equilibrium NO pressure was reached after each pulse of $\mathrm{NO}$, an IR spectrum was acquired. Note that our highest NO pressure of $\sim 0.5$ Torr was specifically chosen in order to avoid formation of $\mathrm{Cu}$-dinitrosyl or even polynitrosyl complexes.

\section{RESULTS}

3.1. DFT Results. In the SSZ-13 zeolite, previous experimental results have shown that the most favorable location for the $\mathrm{Cu}$ ion is in the face of a $6 \mathrm{MR}$ site. ${ }^{5-7} \mathrm{Cu}$ ions in this site have also been suggested to be catalytically active for the $\mathrm{NH}_{3}-\mathrm{SCR}$ reaction. ${ }^{5,7,12}$ We first examined the local structures of $\mathrm{Cu}$ ions in the $6 \mathrm{MR}$ site of $\mathrm{ZCu}$ and $\mathrm{Z}_{2} \mathrm{Cu}$, as shown in Figure 2. It was found that the $\mathrm{Cu}$ ions are 3 -fold and
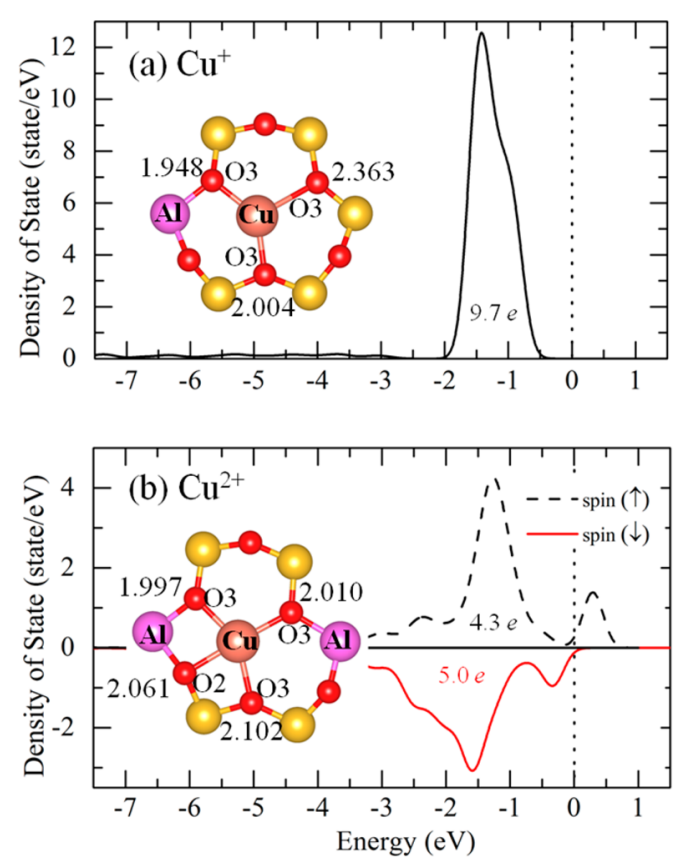

Figure 2. PDOS of $\mathrm{Cu} 3 \mathrm{~d}$ states in (a) $\mathrm{ZCu}$ and (b) $\mathrm{Z}_{2} \mathrm{Cu}$. Insets are the local structures of $\mathrm{Cu}$ in the $6 \mathrm{MR}$ sites. $\mathrm{Cu}-\mathrm{O}$ bond lengths are indicated in units of $\AA$. Different types of lattice $\mathrm{O}$ atoms can be found in Figure 1. The numbers of integrated electrons from PDOS plots are shown. In (b), the dash and solid lines show spin-up- and spin-down states for $\mathrm{Cu} 3 \mathrm{~d}$, respectively, and the dotted vertical line highlights the location of the Fermi level. Spheres for Si and O depicted as in Figure 1 , with $\mathrm{Cu}$ being shown as large pink balls and $\mathrm{Al}$ as purple ones.

4-fold coordinated to lattice $\mathrm{O}$ atoms for $\mathrm{ZCu}$ and $\mathrm{Z}_{2} \mathrm{Cu}$, respectively. For $\mathrm{ZCu}$, the $\mathrm{Cu}$ ion coordinates with three $\mathrm{O} 3$ atoms and the shortest bond length of $1.948 \AA$ occurs between $\mathrm{Cu}$ and the $\mathrm{O} 3$ atom adjacent to the Al-substituted site. For $\mathrm{Z}_{2} \mathrm{Cu}$, in addition to three $\mathrm{O} 3$ atoms, the $\mathrm{Cu}$ ion also coordinates with an $\mathrm{O} 2$ atom adjacent to the $\mathrm{Al}$-substituted site. These results are consistent with previous computational results reported by McEwen et al. ${ }^{12}$ Examination of the partial density of state (PDOS) for $\mathrm{Cu}$ ions in $\mathrm{ZCu}$ and $\mathrm{Z}_{2} \mathrm{Cu}$ confirms that $\mathrm{Cu}$ ions are in +1 and +2 oxidation states, respectively. For $\mathrm{ZCu}$, the +1 oxidation state is evidenced by the completely filled $3 \mathrm{~d}$ state $\left(9.7 \mathrm{e}\right.$ ), as shown in Figure 2a. For $\mathrm{Z}_{2} \mathrm{Cu}$, a peak exists above the Fermi level in the PDOS plot of the $\mathrm{Cu} 3 \mathrm{~d}$ spin up state indicating an electron loss in the $\mathrm{Cu} 3 \mathrm{~d}$ state. This is confirmed by the integrated $\mathrm{Cu} 3 \mathrm{~d}$ electrons of $4.3 \mathrm{e}$ (spin up) and 5.0 e (spin down), as displayed in Figure $2 \mathrm{~b}$. These results demonstrate that the $\mathrm{Cu}$ ion has $\mathrm{a}+2$ oxidation state in $\mathrm{Z}_{2} \mathrm{Cu}$. 
Figure 3 displays the local structures of $\mathrm{NO}$ adsorbed on $\mathrm{ZCu}$ and $\mathrm{Z}_{2} \mathrm{Cu}\left(\mathrm{ZCu}-\mathrm{NO}\right.$ and $\left.\mathrm{Z}_{2} \mathrm{Cu}-\mathrm{NO}\right)$, as well as the

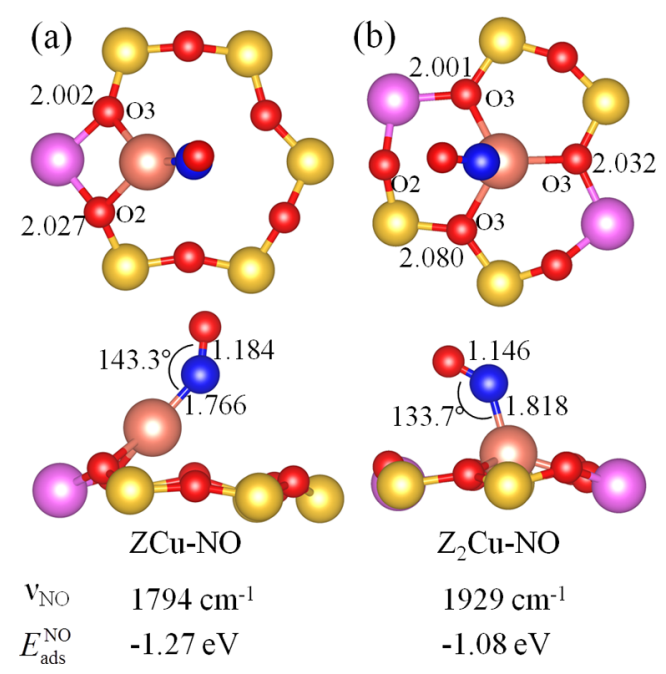

Figure 3. Top and side views of structures for $\mathrm{NO}$ adsorbed on $\mathrm{ZCu}$ and $\mathrm{Z}_{2} \mathrm{Cu}$, shown as (a) $\mathrm{ZCu}-\mathrm{NO}$ and (b) $\mathrm{Z}_{2} \mathrm{Cu}-\mathrm{NO}$, respectively. The adsorption energies calculated by eq 1 as well as $\mathrm{NO}$ frequencies $\left(\nu_{\mathrm{NO}}\right)$ are presented at the bottom of the figure. The spheres for $\mathrm{Si}, \mathrm{O}, \mathrm{Cu}, \mathrm{Al}$ atoms are same as in previous figures. The blue sphere denotes a $\mathrm{N}$ atom.

frequencies and the adsorption energies of NO. With NO adsorption, the $\mathrm{Cu}$ ions still maintain 3-fold and 4-fold coordination numbers for $\mathrm{ZCu}$ and $\mathrm{Z}_{2} \mathrm{Cu}$. For $\mathrm{ZCu}-\mathrm{NO}$, the formation of a $\mathrm{Cu}-\mathrm{N}$ bond is accompanied by the breaking of two $\mathrm{Cu}-\mathrm{O} 3$ bonds and the formation of a $\mathrm{Cu}-\mathrm{O} 2$ bond. For $\mathrm{Z}_{2} \mathrm{Cu}-\mathrm{NO}$, in contrast, the $\mathrm{Cu}-\mathrm{N}$ bond formation causes cleavage of the $\mathrm{Cu}-\mathrm{O} 2$ bond. The adsorption energy for $\mathrm{NO}$ in $\mathrm{ZCu}-\mathrm{NO}(-1.27 \mathrm{eV})$ is $0.19 \mathrm{eV}$ stronger than that in $\mathrm{Z}_{2} \mathrm{Cu}-\mathrm{NO}$ $(-1.08 \mathrm{eV})$. This difference is consistent with the calculated $\mathrm{Cu}-\mathrm{N}$ bond lengths, $1.766 \AA$ in $\mathrm{ZCu}-\mathrm{NO}$ and $1.818 \AA$ in $\mathrm{Z}_{2} \mathrm{Cu}-$ $\mathrm{NO}$, also displayed in Figure 3. As demonstrated above, the $\mathrm{Cu}$ ions in $\mathrm{ZCu}$ and $\mathrm{Z}_{2} \mathrm{Cu}$ are $\mathrm{Cu}^{+}$and $\mathrm{Cu}^{2+}$, respectively. The $\mathrm{NO}$ adsorption energy and $\mathrm{Cu}-\mathrm{N}$ bond length differences are expected to be caused by these $\mathrm{Cu}$ ion oxidation state differences. Note also that the interaction between the NO $\pi^{*}$ state and the $\mathrm{Cu} 3 \mathrm{~d}$ state forbids a linear geometry, ${ }^{21}$ thus resulting in $\mathrm{Cu}-\mathrm{N}-\mathrm{O}$ angles of $143.3^{\circ}$ and $133.7^{\circ}$ for $\mathrm{ZCu}-\mathrm{NO}$ and $\mathrm{Z}_{2} \mathrm{Cu}-\mathrm{NO}$, respectively.

The calculated stretching vibrational frequencies $\left(\nu_{\mathrm{NO}}\right)$ for $\mathrm{ZCu}-\mathrm{NO}$ and $\mathrm{Z}_{2} \mathrm{Cu}-\mathrm{NO}$ are 1794 and $1929 \mathrm{~cm}^{-1}$, which are consistent with computational results by using cluster ${ }^{17}$ and periodic $^{21}$ models. Note that gas phase NO has $\nu_{\text {NO }}$ of 1896 $\mathrm{cm}^{-1}$. These vibrational frequencies agree well with the calculated $\mathrm{N}-\mathrm{O}$ bond lengths. The $\mathrm{N}-\mathrm{O}$ bond lengths for $\mathrm{ZCu}-\mathrm{NO}$, gas phase $\mathrm{NO}$ and $\mathrm{Z}_{2} \mathrm{Cu}-\mathrm{NO}$ are 1.184, 1.169, and $1.146 \AA$, respectively.

NO chemisorption shown above only considers the simplest situation (i.e., naked $\mathrm{Cu}$ ions located in faces of $6 \mathrm{MR}$ ). However, the practical $\mathrm{NH}_{3}-\mathrm{SCR}$ reaction conditions are rather complicated. In order for our calculations to be more relevant, complexities are added in the following calculations. Namely, we attempt to investigate $\mathrm{NO}$ adsorption under three conditions: (1) on $\mathrm{Cu}$ sites in different charge balancing locations of the chabazite structure; (2) in the presence of
Brønsted acid sites; and (3) in the presence of extra framework ligands (i.e., $-\mathrm{OH}$ and $\mathrm{H}_{2} \mathrm{O}$ ).

In addition to the 6MR site shown in Figure 3, SSZ-13 offers various potential sites for $\mathrm{Cu}$ ions. A variation of the distribution of the $\mathrm{Al}$ atoms among the $\mathrm{T}$-sites leads to different cation structures for $\mathrm{Cu} / \mathrm{SSZ}-13$. For the location of the $\mathrm{Cu}^{+}$cation, our recent results show that the $6 \mathrm{MR}$ site is more favorable than the $8 \mathrm{MR}$ sites with an energy difference about $0.5 \mathrm{eV} .^{33}$ Göltl et al. considered eight possible different cation structures for $\mathrm{Cu}^{2+} / \mathrm{SSZ}-13$ and concluded that the most favorable structure is when both $\mathrm{Al}$ atoms and the $\mathrm{Cu}^{2+}$ cation are located within the same $6 \mathrm{MR}$, with the two $\mathrm{Al}$ atoms distributed in a AlSiSiAl configuration. ${ }^{24}$ By studying the $\mathrm{CO}$ frequencies adsorbed on the $\mathrm{Cu}^{2+}$ cation in different structures, they found that the change in the local environment changes the frequencies of the adsorbed CO molecule. ${ }^{24}$ The question here is what happens to the NO molecule for such local environment changes. We systematically investigated the effect of the $\mathrm{Cu}$ position and $\mathrm{Al}$ atoms distribution on the frequencies of the adsorbed NO molecule. A detailed description can be found in the Figure S2 of the Supporting Information. It is found that the change of the $\mathrm{Cu}^{+}$location does not change the $\mathrm{NO}$ stretch frequency considerably for the $\mathrm{ZCu}-\mathrm{NO}$ systems. However, for $\mathrm{NO}$ adsorbed on $\mathrm{Cu}^{2+}$ ion, the $\mathrm{NO}$ frequency is dependent on not only the $\mathrm{Cu}$ location but also on the distribution of the two $\mathrm{Al}$ atoms. For example, when a $\mathrm{Cu}^{2+}$ ion is in a $6 \mathrm{MR}$ site, a change from an $\mathrm{AlSiAl}$ distribution to an AlSiSiAl configuration results in an increase of the NO frequency from 1901 to $1929 \mathrm{~cm}^{-1}$. With the same AlSiSiAl distribution, the NO frequency varies from $1929 \mathrm{~cm}^{-1}$ to 1918 and $1932 \mathrm{~cm}^{-1}$ when the $\mathrm{Cu}$ position changes from the $6 \mathrm{MR}$ to the $8 \mathrm{MR}$ sites, although $\mathrm{Cu}$ in an $8 \mathrm{MR}$ is less favorable than in a $6 \mathrm{MR}$ site. We conclude that the local $\mathrm{Cu}^{2+}$ environment changes the frequencies of the adsorbed $\mathrm{NO}$, which is similar to the results for $\mathrm{CO}$ as reported by Göltl et al. ${ }^{24}$

Concerning the presence of Brønsted acid sites, as shown in Figure 1, there are four nonequivalent $\mathrm{O}$ sites in the SSZ-13 framework. First, we investigate the simple situation where only the Brønsted acid sites exist in SSZ-13 (H/SSZ-13) (i.e., replacing one $\mathrm{Si}$ atom by one $\mathrm{Al}$ atom and using an $\mathrm{H}$ atom to compensate the charge deficit). These have already been investigated by DFT methods in the literature. ${ }^{19,34}$ The stability of the Brønsted acid sites is found to decrease in the sequence of $\mathrm{O} 1>\mathrm{O} 2>\mathrm{O} 3>\mathrm{O} 4$, which is consistent with previous results reported by Suzuki et al. ${ }^{34}$ and Göltl et al. ${ }^{19}$ In addition, the calculated $\mathrm{Al}-\mathrm{O}$ bond length is also in line with those works. Detailed information can be found in Table S1 of the Supporting Information. Similarly, due to the existence of four nonequivalent $\mathrm{O}$ sites, four possible Brønsted acid site locations can be arranged next to an $\mathrm{Al} \mathrm{T}$ site in $\mathrm{Z}_{2} \mathrm{Cu}$, namely, $\mathrm{O} 1, \mathrm{O} 2$, $\mathrm{O} 3$ and $\mathrm{O} 4$ sites, as shown in Figure 4. The calculated bond lengths and energies are summarized in Table 1 . The introduction of a Brønsted acid site into $\mathrm{Z}_{2} \mathrm{Cu}$ decreases the $\mathrm{Cu}$ coordination number from 4 to 3 . The $\mathrm{Al}-\mathrm{O}$ bond lengths change slightly with different locations of the Brønsted acid site. Note especially the configuration where the Brønsted acid site is located in the $\mathrm{O} 3$ site. In this configuration, the bond length for $\mathrm{Cu}-\mathrm{O} 3$ is $2.023 \AA$, larger than the $\mathrm{Cu}-\mathrm{O} 3$ bond lengths when Brønsted acid sites are located on $\mathrm{O} 1, \mathrm{O} 2$, and $\mathrm{O} 4$, as shown in Figure 4. It is also found that the $\mathrm{O} 3$ Brønsted acid site is energetically the least favorable one, with $\Delta E_{1}=0.88 \mathrm{eV}$, as shown in Table 1. Although the $\Delta E_{1}$ values for the $\mathrm{O} 2$ and O4 Brønsted acid sites are rather small, the O1 Brønsted acid 


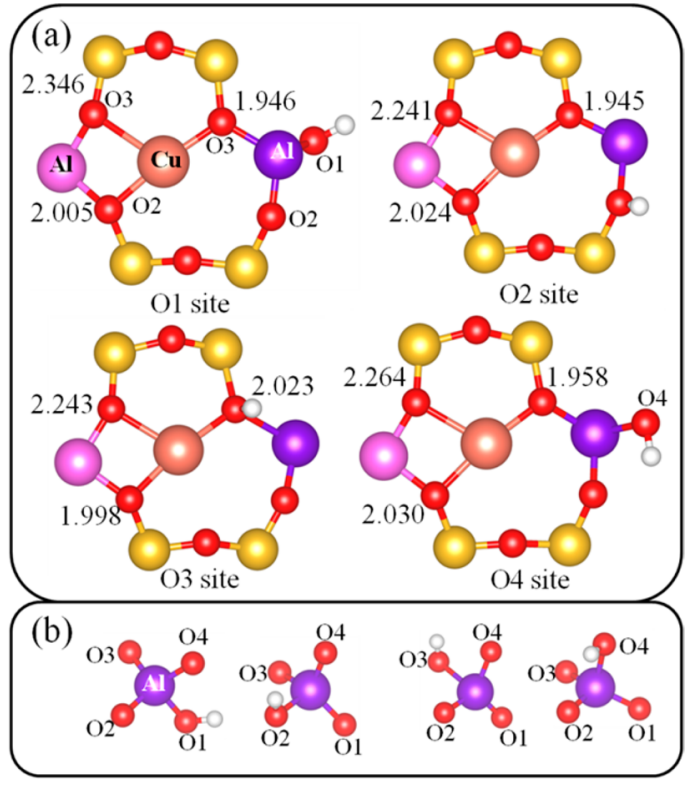

Figure 4. (a) Local structures of a six-membered ring in the presence of a Brønsted acid site and a $\mathrm{Cu}$ atom. (b) Corresponding local structure of the tetrahedral $\mathrm{Al}$ site that is adjacent to the Brønsted acid site. The spheres for $\mathrm{Si}, \mathrm{O}, \mathrm{Cu}$, and $\mathrm{Al}$ atoms are the same as in previous figures. The dark $\mathrm{Al}$ represents the location of the tetrahedral Brønsted acid site. The small white spheres represent the $\mathrm{H}$ atoms.

Table 1. Al-O Bond Lengths ( $\AA$ ) for the Four Configurations Shown in Panel b of Figure $4^{a}$

$\begin{array}{ccccccc}\begin{array}{c}\text { Brønsted acid } \\ \text { site }\end{array} & \mathrm{Al}-\mathrm{O} 1 & \mathrm{Al}-\mathrm{O} 2 & \mathrm{Al}-\mathrm{O} 3 & \mathrm{Al}-\mathrm{O} 4 & \mathrm{O}-\mathrm{H} & \begin{array}{c}\Delta E_{1} \\ (\mathrm{eV})\end{array} \\ \mathrm{O} 1 & \mathbf{1 . 9 1 5} & 1.696 & 1.800 & 1.693 & 0.977 & 0.00 \\ \mathrm{O} 2 & 1.704 & \mathbf{1 . 8 8 1} & 1.802 & 1.700 & 0.978 & 0.08 \\ \mathrm{O} 3 & 1.700 & 1.696 & \mathbf{2 . 1 8 8} & 1.691 & 0.988 & 0.88 \\ \mathrm{O} 4 & 1.712 & 1.720 & 1.797 & \mathbf{1 . 8 8 1} & 0.983 & 0.14\end{array}$

${ }^{a} \Delta E_{1}$ is the energy difference of $\mathrm{HZ}_{2} \mathrm{Cu}$ with different locations of the Brønsted acid site, with respect to the total energy of the O1 Brønsted acid site. Positive values designate less favorable sites than the $\mathrm{O} 1$ Brønsted acid site.

site configuration is clearly the most stable one, and only this structure will be further considered in the following. We also note that in all configurations, the $\mathrm{Al}-\mathrm{O}(\mathrm{H})$ bond length is always longer than the other three $\mathrm{Al}-\mathrm{O}$ bonds (highlighted in Table 1).

Next, we investigate different $\mathrm{Cu}$ positions in $\mathrm{HZ}_{2} \mathrm{Cu}$ by fixing the Brønsted acid site in the $\mathrm{O} 1$ location. Figure 5 displays the local structures of $\mathrm{HZ}_{2} \mathrm{Cu}$ with $\mathrm{Cu}$ in both $6 \mathrm{MR}$ and $8 \mathrm{MR}$ positions. $\mathrm{Cu}$ in the $6 \mathrm{MR}$ site has a 3 -fold coordination to lattice $\mathrm{O}$ atoms (two $\mathrm{O} 3$ and one $\mathrm{O} 2$ ); for the two positions of $\mathrm{Cu}$ in the $8 \mathrm{MR}$ sites, $\mathrm{Cu}$ atoms are either bonded with the $\mathrm{O} 1$ and $\mathrm{O} 4$ atoms (denoted as the 8MR O14 site) or the $\mathrm{O} 2$ and $\mathrm{O} 4$ atoms (8MR_O24 site). All calculated $\mathrm{Cu}-\mathrm{O}$ bond lengths for the three configurations are displayed in Figure 5.

Table 2 presents calculated energy differences $\left(\Delta E_{2}\right)$ for the three "naked" $\mathrm{HZ}_{2} \mathrm{Cu}$ configurations, as well as configurations

Table 2. Energy Differences $\Delta E_{2}$ As Defined in the Text ${ }^{a}$

\begin{tabular}{lccc}
\multicolumn{1}{c}{$\Delta E_{2}(\mathrm{eV})$} & $6 \mathrm{MR}$ & $8 \mathrm{MR} \_\mathrm{O} 14$ & $8 \mathrm{MR} \_\mathrm{O} 24$ \\
$\mathrm{HZ}{ }_{2} \mathrm{Cu}$ & 0.00 & 1.00 & 0.89 \\
$\mathrm{HZ}{ }_{2} \mathrm{Cu}-\mathrm{NO}$ & 0.00 & -0.07 & 0.08 \\
$\mathrm{HZ}_{2} \mathrm{Cu}-\mathrm{OH}$ & 0.00 & -0.56 & 0.02 \\
$\mathrm{HZ}_{2} \mathrm{Cu}-\mathrm{H}_{2} \mathrm{O}$ & 0.00 & -0.18 & -0.19 \\
$\mathrm{HZ}{ }_{2} \mathrm{Cu}-(\mathrm{NO}+\mathrm{OH})$ & 0.00 & -0.60 & 0.25
\end{tabular}

${ }^{a_{T}}$ The positive and negative values present less and more favorable positions, respectively, as compared to the corresponding scenario with $\mathrm{Cu}$ in a $6 \mathrm{MR}$ position.

with chemisorbed species $\left(\mathrm{NO}, \mathrm{OH}, \mathrm{H}_{2} \mathrm{O}\right.$, and $\left.\mathrm{NO}+\mathrm{OH}\right)$, using the corresponding configurations for $\mathrm{Cu}$ in the $6 \mathrm{MR}$ site as the zero energy references. Without adsorbates, the $6 \mathrm{MR}$ is clearly the energetically more favorable site; the 8MR_O14 and $8 \mathrm{MR} \mathrm{O} 24$ sites are 1.00 and $0.89 \mathrm{eV}$, respectively, energetically less favorable. However, with $\mathrm{NO}$ and $\mathrm{H}_{2} \mathrm{O}$ as adsorbates, the difference greatly diminishes and the $8 \mathrm{MR}$ sites can even become slightly more favorable (except for 8MR_O24-NO). More importantly, in the cases of $\mathrm{OH}$ and $\mathrm{NO}^{-}+\mathrm{OH}$ as adsorbates, the 8MR_O14 conformation is energetically substantially more favorable $\left(\Delta E_{2} \sim-0.6 \mathrm{eV}\right)$. In the following, more details are given on these calculated results.

As displayed in Figure 6, in all three $\mathrm{HZ}_{2} \mathrm{Cu}-\mathrm{NO}$ configurations, $\mathrm{Cu}$ displays 2 -fold coordination with lattice oxygen. The adsorption of $\mathrm{NO}$ on $\mathrm{HZ}_{2} \mathrm{Cu}$ in a $6 \mathrm{MR}\left(E_{\mathrm{ads}}^{\mathrm{NO}}=\right.$ $-0.96 \mathrm{eV})$ is weaker than that on $\mathrm{ZCu}\left(E_{\text {ads }}^{\mathrm{NO}}=-1.27 \mathrm{eV}\right.$, Figure 3). However, when $\mathrm{NO}$ is adsorbed on $\mathrm{HZ}_{2} \mathrm{Cu}$ associated with

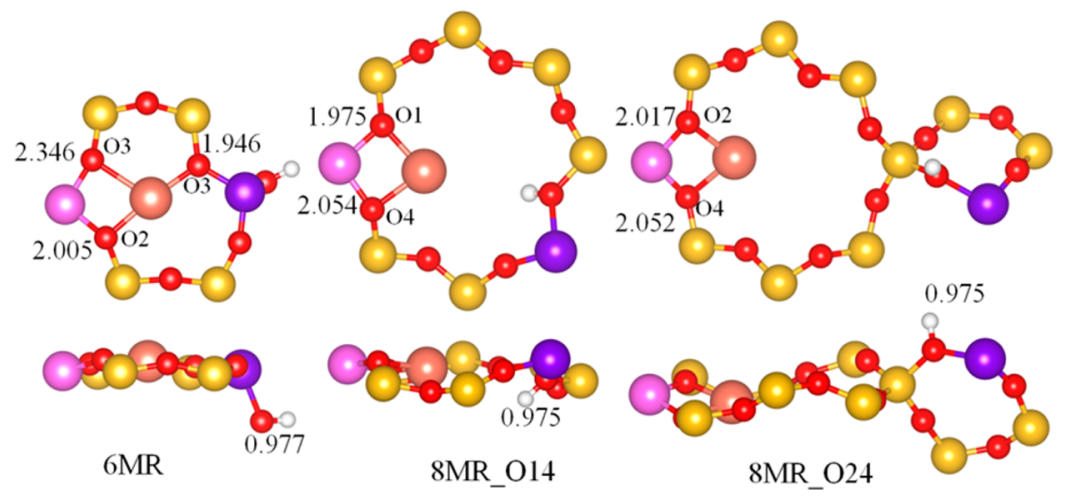

Figure 5. Local structures of three possible $\mathrm{Cu}$ positions (6MR, $8 \mathrm{MR} \_\mathrm{O} 14$ and $\left.8 \mathrm{MR} \_\mathrm{O} 24\right)$ in $\mathrm{HZ}_{2} \mathrm{Cu}$. Note that $\mathrm{Al}$ and $\mathrm{H}$ atoms are in the same position when varying positions of $\mathrm{Cu}$ and that an extended part of the zeolite is shown for $\mathrm{Cu}$ in the $8 \mathrm{MR} \mathrm{O} 24$, so as to show the location of both Al sites. The Brønsted acid site locates in the $\mathrm{O} 1$ site. The $\mathrm{Cu}-\mathrm{O}$ distances $(\AA)$ are indicated in each panel. The color schemes for different atoms are the same as in previous figures, and the nonequivalent $\mathrm{O}$ atoms are identified in Figure 1. 


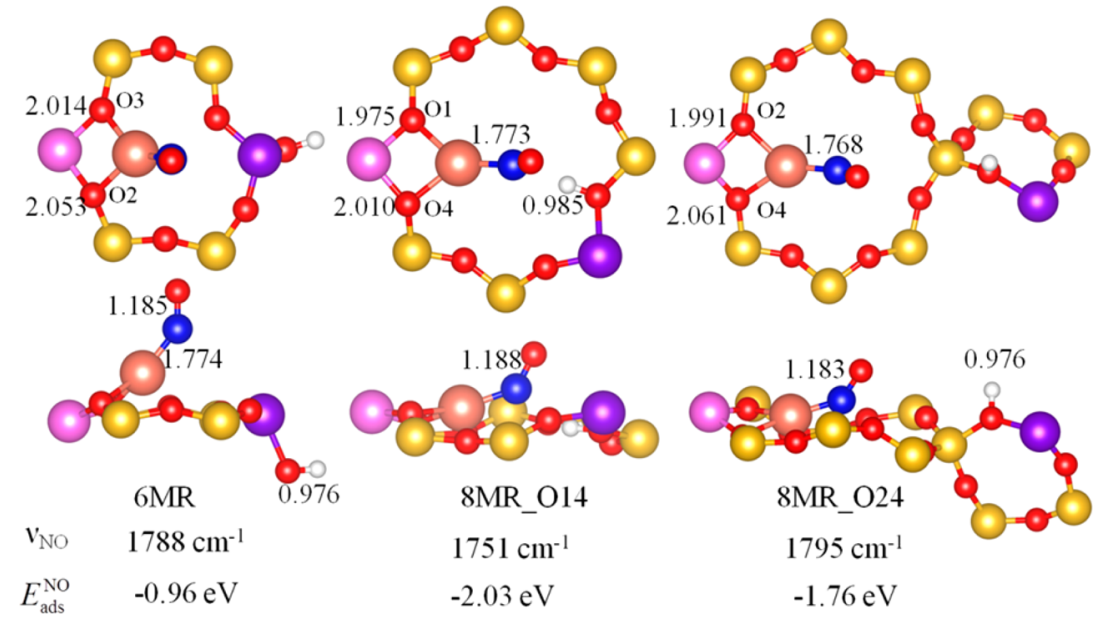

Figure 6. Local structures of $\mathrm{NO}$ adsorbed in a $\mathrm{HZ}_{2} \mathrm{Cu}$ conformation with $\mathrm{Cu}$ in a $6 \mathrm{MR}, 8 \mathrm{MR} \mathrm{O} 14$, and a $8 \mathrm{MR}$ O24 conformation. The color coding for the spheres have the same meaning as previous figures, and the given distances are bond lengths in $\AA$ units. The NO frequencies and adsorption energies of $\mathrm{NO}$ are indicated at the bottom of the figure.

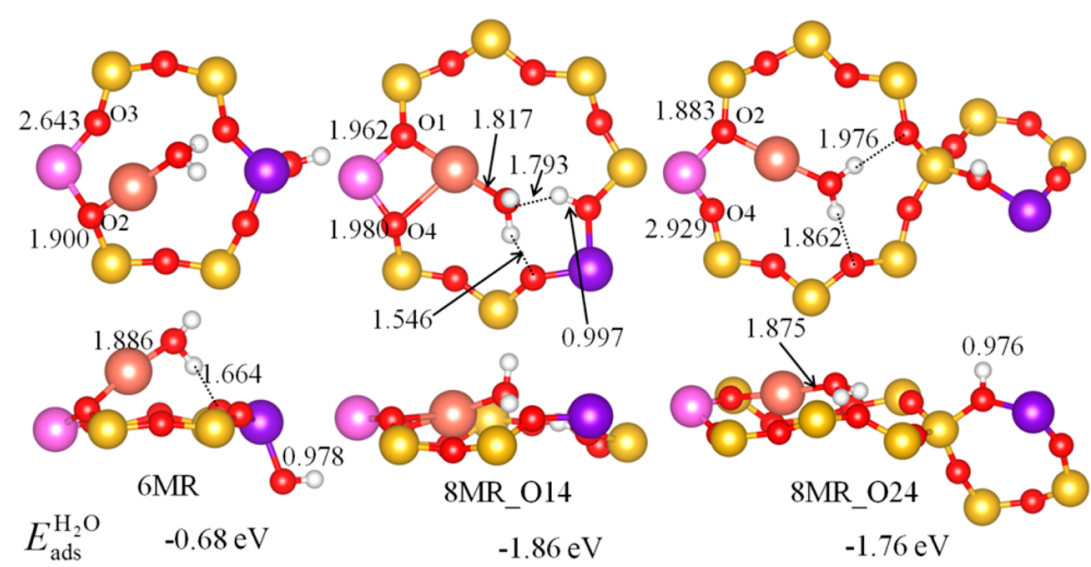

Figure 7. Local structures of $\mathrm{H}_{2} \mathrm{O}$ adsorbed onto $\mathrm{HZ}_{2} \mathrm{Cu}$ with $\mathrm{Cu}$ in the $6 \mathrm{MR}, 8 \mathrm{MR} \_\mathrm{O} 14$, and 8MR_O24 sites. The color coding for the spheres and given distances have the same meaning as previous figures. The adsorption energies of $\mathrm{H}_{2} \mathrm{O}$ are indicated at the bottom of the figure.

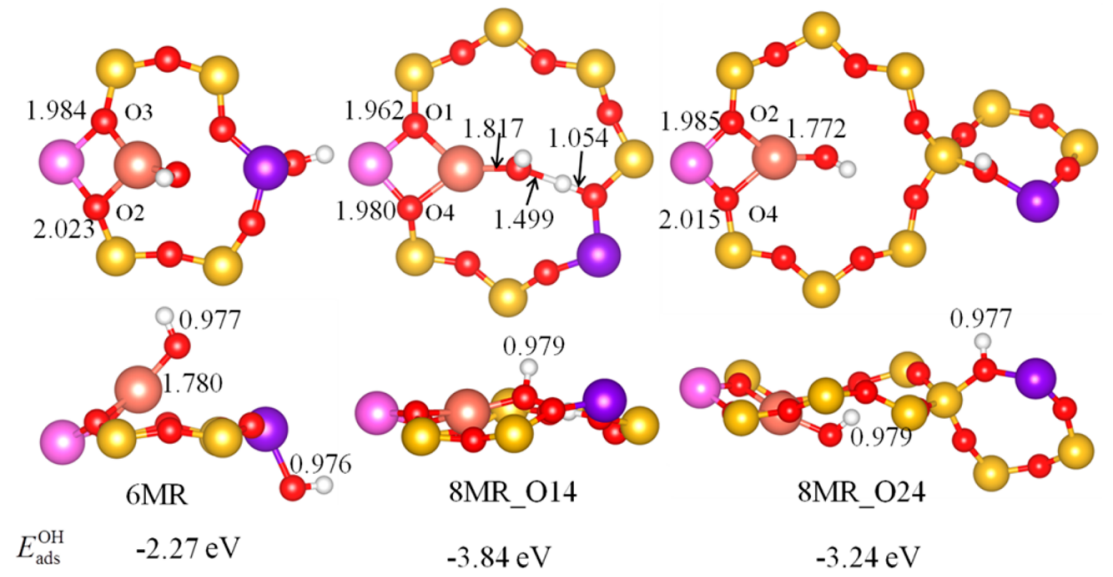

Figure 8. Local structures of $\mathrm{OH}$ adsorbed on $\mathrm{HZ}_{2} \mathrm{Cu}$ with $\mathrm{Cu}$ in the $6 \mathrm{MR}, 8 \mathrm{MR} \_\mathrm{O} 14$, and 8MR_O24 sites. The color coding for the spheres and given distances have the same meaning as previous figures. The adsorption energies of $\mathrm{OH}$ are indicated at the bottom of the figure.

8MRs, much stronger adsorption energies are obtained. Importantly, these energies are sufficiently high to compensate for the instability of "naked" $\mathrm{Cu}$ ions in 8MRs, making the 8MR_O14-NO conformation the energetically more favorable configuration (Table 2). The frequencies of $\mathrm{NO}$ adsorbed on $\mathrm{Cu}$ in $6 \mathrm{MR}, 8 \mathrm{MR} \_\mathrm{O} 14$ and $8 \mathrm{MR} \_\mathrm{O} 24$ sites of $\mathrm{HZ}_{2} \mathrm{Cu}$ are
1788,1751 , and $1795 \mathrm{~cm}^{-1}$, respectively. Different from the case of $\mathrm{Cu}^{+}$in the $\mathrm{ZCu}-\mathrm{NO}$ system, where the location of the $\mathrm{Cu}^{+}$results in a very weak effect on NO frequency, the NO frequency in the $\mathrm{HZ}_{2} \mathrm{Cu}-\mathrm{NO}$ decreases from 1788 to 1751 $\mathrm{cm}^{-1}$ when $\mathrm{Cu}$ migrates from the $6 \mathrm{MR}$ to the $8 \mathrm{MR}$-O14 site and increases from 1788 to $1795 \mathrm{~cm}^{-1}$ when $\mathrm{Cu}$ migrates from 


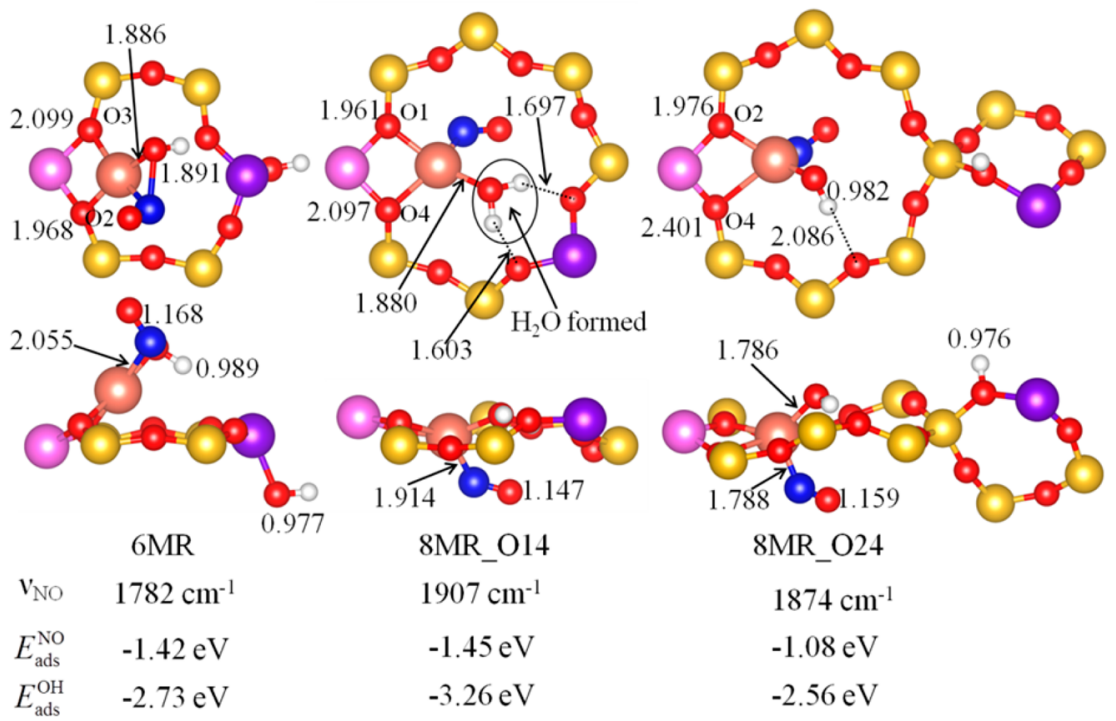

Figure 9. Local structures of $\mathrm{NO}$ and $\mathrm{OH}$ coadsorbed on $\mathrm{HZ}_{2} \mathrm{Cu}$ with $\mathrm{Cu}$ in the $6 \mathrm{MR}, 8 \mathrm{MR}$ O 14 , and 8MR_O24 sites. The color coding for the spheres and given distances have the same meaning as previous figures. The adsorption energies of $\mathrm{NO}$ and $\overline{\mathrm{OH}}$ are indicated at the bottom of the figure.

the $6 \mathrm{MR}$ to the $8 \mathrm{MR}$ O24 site. We conclude that the local environment of $\mathrm{Cu}$ changes the strength of the adsorbed NO molecule in the presence of a Brønsted acid site. As mentioned before, the oxidation state of $\mathrm{Cu}$ in $\mathrm{HZ}_{2} \mathrm{Cu}$ should be +1 to maintain charge neutrality. These vibrational frequencies confirm that $\mathrm{Cu}$ in all three $\mathrm{HZ}_{2} \mathrm{Cu}$ configurations is indeed $\mathrm{Cu}^{+}$.

Figure 7 presents calculated results for $\mathrm{H}_{2} \mathrm{O}$ adsorption on the three $\mathrm{HZ}_{2} \mathrm{Cu}$ structures. Upon bond formation with $\mathrm{H}_{2} \mathrm{O}$, $\mathrm{Cu}$ only displays single coordination with lattice oxygen in 6MR and 8MR_O24, while in the 8MR_O14, 2-fold coordination with lattice oxygen still maintains. Chemisorbed $\mathrm{H}_{2} \mathrm{O}$ has apparent hydrogen bond interactions with lattice oxygen in all cases, where the shortest distances between a $\mathrm{H}$ atom in $\mathrm{H}_{2} \mathrm{O}$ and the lattice $\mathrm{O}$ atoms are 1.664, 1.546, and $1.862 \AA$ in the $6 \mathrm{MR}, 8 \mathrm{MR} \mathrm{O} 14$, and $8 \mathrm{MR} \mathrm{O} 24$ sites, respectively. Again, adsorption energies for $\mathrm{HZ}_{2} \mathrm{Cu}-\mathrm{H}_{2} \mathrm{O}$ within the 8MR_O14 and 8MR_O24 sites are substantially greater than that in $6 \mathrm{MR}$, enough to overcome the instability of "naked" $\mathrm{Cu}$ ions in $8 \mathrm{MRs}$. As such, both $8 \mathrm{MR}$ sites are energetically more favorable (Table 2).

The interaction between $\mathrm{OH}$ and $\mathrm{HZ}_{2} \mathrm{Cu}$ is very strong, with adsorption energies in the $6 \mathrm{MR}$, the $8 \mathrm{MR} \mathrm{O} 14$ and the 8MR_O24 sites being $-2.36,-3.84$, and $-3.25 \mathrm{eV}$, respectively. As shown in Figure 8 , for the most stable $\mathrm{HZ}_{2} \mathrm{Cu}-\mathrm{OH}$ structure in the $8 \mathrm{MR} \mathrm{O} 14$ position, the distance between the $\mathrm{O}$ atom of the adsorbed $\mathrm{OH}$ and the $\mathrm{H}$ atom of the Brønsted acid site is $1.499 \AA$. This distance is slightly longer than a valence bond which involves $\mathrm{H}$ but shorter than typical distances for hydrogen bonded interactions. This quasi bond formation extensively stabilizes the chemisorbed hydroxyl, giving a $\Delta E_{2}$ value of $-0.56 \mathrm{eV}$ as shown in Table 2 . In addition, this quasi bond formation elongates the $\mathrm{O}-\mathrm{H}$ bond length of the Brønsted acid site (1.054 $\AA$ ), as compared to the Brønsted acid site without $\mathrm{OH}$ adsorption (0.975 $\AA$ ). It is reported that GGA and hybrid functionals lead to very different results for the location of the cation $\mathrm{d}$ and $\mathrm{s}$ states relative to the energy bands of the framework. ${ }^{20}$ In order to compare results obtained with a hybrid functional to the GGA-PW91 functional used in this study, we recalculated the $\mathrm{HZ}_{2} \mathrm{Cu}-\mathrm{OH}$ systems using the hybrid HSE06 functional. ${ }^{35}$ By using the HSE06 functional, the calculated values of the total energy differences $\left(\Delta E_{2}\right)$ are found to be -0.59 and $0.07 \mathrm{eV}$ for $\mathrm{Cu}$ in a 8MR_O14 and a 8MR_O24 sites, respectively. There is no difference between these results and those calculated by the GGA-PW91 functional which are -0.56 and $0.02 \mathrm{eV}$ for $\mathrm{Cu}$ in 8MR_O14 and 8MR_O24 sites, respectively (shown in Table 2). $\bar{W}$ e therefore conclude that the HSE06 hybrid functional does not change the $\mathrm{OH}$ stabilization effect of $\mathrm{Cu}$ in the $8 \mathrm{MR}$ and the energetic order. However, it has been reported that large discrepancies arise when using the two functional to calculate adsorption energies. $^{21}$ By using the HSE06 functional, the calculated adsorption energies of $\mathrm{OH}$ on $\mathrm{Cu}$ in a $\mathrm{HZ}_{2} \mathrm{Cu}$ conformation are $-1.88,-3.31$, and $-2.52 \mathrm{eV}$ for $\mathrm{Cu}$ in the $6 \mathrm{MR}, 8 \mathrm{MR} \mathrm{O} 14$, and $8 \mathrm{MR} \mathrm{O} 24$, respectively. These values are considerably lower than the corresponding values calculated by using the GGA-PW91 functional, with differences at 0.49, 0.52 , and $0.73 \mathrm{eV}$, respectively. A detailed comparison between our results calculated with HSE06 functional and results found in the literature is shown in Section 4 of the Supporting Information.

Finally, calculated results on $\mathrm{HZ}_{2} \mathrm{Cu}-(\mathrm{NO}+\mathrm{OH})_{\text {ads }}$ are shown in Figure 9. In our calculations, $\mathrm{NO}$ and $\mathrm{OH}$ are restricted to the same side of $6 \mathrm{MR}$ while they are placed on two sides of $8 \mathrm{MR}$ to release space crowding. Interestingly, in the case for $\mathrm{Cu}$ in the $6 \mathrm{MR}$ site, $\mathrm{NO}$ and $\mathrm{OH}$ interact to form HONO upon relaxation, an important intermediate proposed previously in $\mathrm{NH}_{3}-\mathrm{SCR}^{36}$ In the $8 \mathrm{MR}$ sites, they remain separated upon relaxation. For $\mathrm{Cu}$ in the $6 \mathrm{MR}$ site, coadsorption with $\mathrm{OH}$ does not significantly change the NO vibrational frequency $\left(1782 \mathrm{~cm}^{-1}\right)$, as compared to that of $\mathrm{NO}$ adsorption alone $\left(1788 \mathrm{~cm}^{-1}\right.$, Figure 6). When $\mathrm{NO}$ and $\mathrm{OH}$ are coadsorbed on $\mathrm{Cu}$ in the $8 \mathrm{MR}$ O 14 site, the relaxed structure shows $\mathrm{H}_{2} \mathrm{O}$ formation between the adsorbed $\mathrm{OH}$ and the proton from the Brønsted acid site. The $\mathrm{O}-\mathrm{H}$ bond lengths in the formed $\mathrm{H}_{2} \mathrm{O}$ are 1.014 and $1.025 \AA$. In 8MR O14 and the 8MR_O24 sites, NO vibrational frequencies are 1907 and $1874 \mathrm{~cm}^{-1}$, respectively, confirming that in both cases, $\mathrm{Cu}$ ions 
are in +2 oxidation states. Finally, for $\mathrm{Cu}$ in the 8MR O14 and the $8 \mathrm{MR}$ O24 sites, coadsorption weakens the interactions between $\overline{\mathrm{Cu}}$ and the adsorbates. For example, for $\mathrm{Cu}$ in the $8 \mathrm{MR}$ O14 site, the adsorption energies of $\mathrm{NO}$ and $\mathrm{OH}$ are $-1.4 \overline{5}$ and $-3.26 \mathrm{eV}$ upon coadsorption. However, when these species are adsorbed separately, the adsorption energies are -2.03 (Figure 6) and $-3.84 \mathrm{eV}$ (Figure 8), respectively.

3.2. FTIR Results. Previous studies have shown that in $\mathrm{Cu}$ ion-exchanged zeolites, locations of $\mathrm{Cu}$ ions are influenced by multiple factors including zeolite type, $\mathrm{Si} / \mathrm{Al}$ ratio, $\mathrm{Cu}$ ion exchange level (i.e., $\mathrm{Cu}$ loading), and sometimes, synthesis methods. ${ }^{4}$ For the simple SSZ-13 structure, $\mathrm{Cu}$ ion locations can be readily varied by changing $\mathrm{Si} / \mathrm{Al}$ ratios and $\mathrm{Cu}$ ion exchange levels. In this study, we synthesized three SSZ-13 samples with different $\mathrm{Si} / \mathrm{Al}$ ratios. Table 3 presents the $\mathrm{Si}$ and

Table 3. Si, Al Contents and the Corresponding Si/Al Ratios of the Three SSZ-13 Samples Studied Here

\begin{tabular}{cccc} 
SSZ-13 sample & Si content $($ wt \%) & Al content $($ wt \%) & Si/Al \\
1 & 30.4 & 5.03 & 6 \\
2 & 40.3 & 3.23 & 12 \\
3 & 43.4 & 1.20 & 35 \\
\hline
\end{tabular}

$\mathrm{Al}$ contents for these samples, and the corresponding $\mathrm{Si} / \mathrm{Al}$ ratios (6, 12 and 35) calculated on the basis of these values. Note that during the subsequent ion exchange step to obtain $\mathrm{Cu} / \mathrm{SSZ}-13$ samples, no $\mathrm{Si}$ or $\mathrm{Al}$ leaching was found, and therefore, these $\mathrm{Si} / \mathrm{Al}$ ratios were maintained.

As has been addressed in detail in the previous section, a naked $\mathrm{Cu}^{2+}$ ion balances two negative framework charges (as $\mathrm{Z}_{2} \mathrm{Cu}$ ), a naked $\mathrm{Cu}^{+}$ion balances one negative framework charge (as $\mathrm{ZCu}$ ), and a $\mathrm{Cu}^{+} / \mathrm{H}^{+}$pair balances two negative framework charges (as $\mathrm{HZ}_{2} \mathrm{Cu}$ ). It is also shown in the section above that an $-\mathrm{OH}$ group binds strongly with a naked $\mathrm{Cu}^{+}$ion. In this case, $\mathrm{Cu}^{+}$is oxidized to $\mathrm{Cu}^{2+}$, although the nominal charge for this copper center is still +1 , that is, $\left[\mathrm{Cu}^{\mathrm{II}}(\mathrm{OH})\right]^{+}$. Obviously, this species also only balances one negative framework charge. For the formation of stable $\mathrm{Z}_{2} \mathrm{Cu}$, two framework $\mathrm{Al}$ sites, placed in close proximity, are required. Previous studies have shown that the number of accessible Al T sites around a given $\mathrm{Al} \mathrm{T}$ site approximately follows a Poisson distribution. ${ }^{37,38}$ This means that the probability of stable $\mathrm{Z}_{2} \mathrm{Cu}$ formation decreases exponentially as $\mathrm{Si} / \mathrm{Al}$ ratios rise. Very recently, Verma et al. calculated the maximum $\mathrm{Z}_{2} \mathrm{Cu}$ formation in a $6 \mathrm{MR}$ as a function of $\mathrm{Si} / \mathrm{Al}$ ratios. Indeed, the expected exponential decrease as a function of $\mathrm{Si} / \mathrm{Al}$ ratio was found. ${ }^{23}$ Clearly, at very high $\mathrm{Si} / \mathrm{Al}$ ratios (e.g., 35 ), $\mathrm{Z}_{2} \mathrm{Cu}$ formation becomes highly unlikely. Yet, under humid and ambient conditions, experimental studies show that $\mathrm{Cu}$ ions remain in the +2 oxidation state irrespective of $\mathrm{Si} / \mathrm{Al}$ ratio; thus, for $\mathrm{Cu}$ / SSZ-13 samples with low $\mathrm{Si} / \mathrm{Al}$ and high $\mathrm{Cu} / \mathrm{Al}$ ratios, as well as samples with high $\mathrm{Si} / \mathrm{Al}$ ratios, some $\mathrm{Cu}^{2+}$ ions are likely present as $\left[\mathrm{Cu}^{\mathrm{II}}(\mathrm{OH})\right]^{+}$. In our most recent publication, the detection of an $\mathrm{OH}$ vibrational band at $3650 \mathrm{~cm}^{-1}$ (absent for SSZ-13 in $\mathrm{H}$ - and $\mathrm{Na}$-forms) is direct evidence for the existence of $[\mathrm{Cu}(\mathrm{OH})]^{+1} .{ }^{10}$ In a recent publication by Lezcano-Gonzalez et al., ${ }^{25}$ a $3655 \mathrm{~cm}^{-1}$ band, which becomes more intense as $\mathrm{Cu}$ loading increases, was assigned to the same $\left[\mathrm{Cu}^{\mathrm{II}}(\mathrm{OH})\right]^{+}$ species, and these authors calculated the $\nu_{\mathrm{OH}}$ in $\left[\mathrm{Cu}^{\mathrm{II}}(\mathrm{OH})\right]^{+}$ to be $3660 \mathrm{~cm}^{-1}$. $^{25}$ Similarly, Giordanino et al. also assigned a stretching $\mathrm{OH}$ band at $3657 \mathrm{~cm}^{-1}$ to $\nu_{\mathrm{OH}}$ in $[\mathrm{Cu}(\mathrm{OH})]^{+39}$
Figure 10 presents IR spectra obtained after NO exposure of a $\mathrm{Cu} / \mathrm{SSZ}-13$ sample $(\mathrm{Si} / \mathrm{Al}=6, \mathrm{Cu} / \mathrm{Al}=0.45)$ annealed in

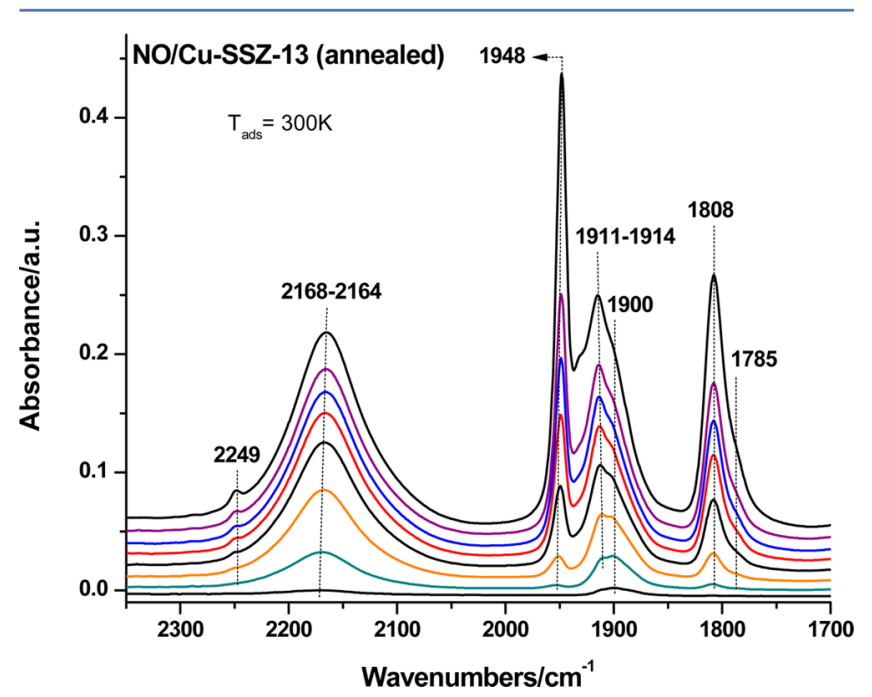

Figure 10. Series of selected IR spectra obtained after exposure of a $\mathrm{Cu} / \mathrm{SSZ}-13$ sample $(\mathrm{Si} / \mathrm{Al}=6, \mathrm{Cu} / \mathrm{Al}=0.4)$ to $\mathrm{NO} 300 \mathrm{~K}$. The sample was annealed in vacuum at $773 \mathrm{~K}$ for $2 \mathrm{~h}$ prior to IR measurements.

vacuum at $500{ }^{\circ} \mathrm{C}$ prior to $\mathrm{NO}$ adsorption. Note that these spectra have been published elsewhere; ${ }^{32}$ however, they are replotted here because they are key to understanding NO chemisorption on the other samples shown below. IR bands centered at $\sim 1808,1900$, and $2165 \mathrm{~cm}^{-1}$ appear immediately after the introduction of the first small NO aliquot $(0.017$ Torr). With the introduction of additional NO doses, the intensities of all of these bands increased together with slight changes in frequencies, and new features developed as well. Notably, new bands at $1785,1910,1930$ (weak), 1948, and 2249 (weak) $\mathrm{cm}^{-1}$ appeared at higher NO pressures. While more details will be given below, briefly, bands at 1785 and $1808 \mathrm{~cm}^{-1}$ are attributed to $\mathrm{NO}$ adsorbed on $\mathrm{Cu}^{+}$sites; bands within the range of $\sim 1850-1950 \mathrm{~cm}^{-1}$ are assigned to NO adsorbed on $\mathrm{Cu}^{2+}$ sites; the broad band centered at $\sim 2165$ $\mathrm{cm}^{-1}$ is attributed to $\mathrm{NO}^{+}$species, and finally, the weak 2249 $\mathrm{cm}^{-1}$ feature belongs to adsorbed $\mathrm{N}_{2} \mathrm{O}$. The stabilities of the adsorbed species represented by these IR absorption features are very different. Bands centered at 1948 and $1930 \mathrm{~cm}^{-1}$ disappear completely after a brief $(\sim 10 \mathrm{~min})$ evacuation at 300 $\mathrm{K}$. The intensity of the $1808 \mathrm{~cm}^{-1}$ band $\left(\mathrm{NO}\right.$ on $\mathrm{Cu}^{+}$) decreases dramatically in the first $10 \mathrm{~min}$ of evacuation, but it retains a small fraction of its intensity. Bands in the 1880-1920 $\mathrm{cm}^{-1}$ spectral region, although with diminished intensities, are also still present after this evacuation step. The most resistant IR feature to evacuation is the one centered at around 2165 $\mathrm{cm}^{-1}$.

Figure 11a presents ambient temperature IR spectra of adsorbed $\mathrm{NO}$ collected on a $\mathrm{Cu} / \mathrm{SSZ}-13$ sample $(\mathrm{Si} / \mathrm{Al}=6$, $\mathrm{Cu} / \mathrm{Al}=0.03)$ annealed in vacuum at $500{ }^{\circ} \mathrm{C}$ prior to $\mathrm{NO}$ adsorption. Note that the $\mathrm{Cu}$ loading in this sample is substantially lower than the one used to collect data for Figure 10. However, the sequence for band development as a function of NO pressure and the relative signal intensities among various bands are strikingly similar to that shown in Figure 10. Still, some subtle differences are evident. Notably, after the first NO dose, a rather distinctive $\mathrm{Cu}^{2+}-\mathrm{NO}$ band was found at 1883 

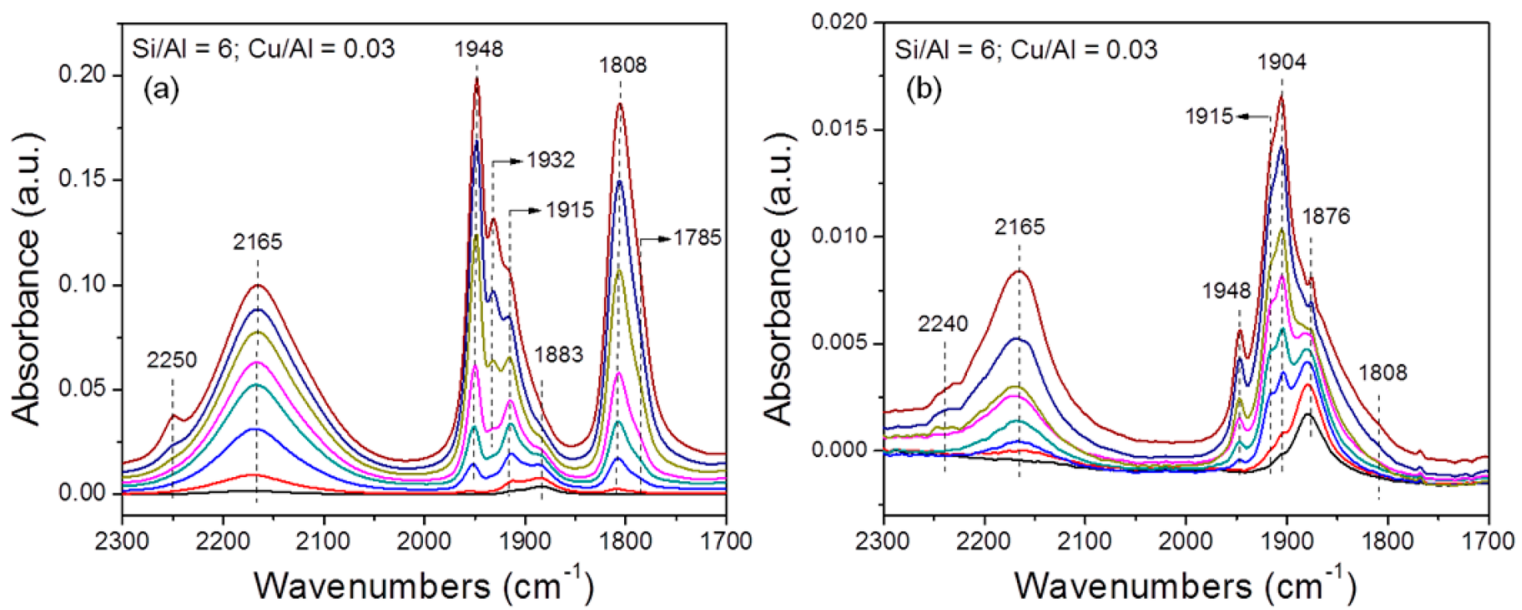

Figure 11. (a) Series of selected IR spectra obtained after exposure of a $\mathrm{Cu} / \mathrm{SSZ}-13$ sample $(\mathrm{Si} / \mathrm{Al}=6, \mathrm{Cu} / \mathrm{Al}=0.03)$ to $\mathrm{NO} 300 \mathrm{~K}$. The sample was annealed in vacuum at $773 \mathrm{~K}$ for $2 \mathrm{~h}$ prior to IR measurements. (b) Series of selected IR spectra obtained after exposure of a Cu/SSZ-13 sample (Si/ $\mathrm{Al}=6, \mathrm{Cu} / \mathrm{Al}=0.03$ ) to $\mathrm{NO} 300 \mathrm{~K}$. The sample was annealed in vacuum at $423 \mathrm{~K}$ for $2 \mathrm{~h}$ prior to IR measurements. Note that after this latter lowtemperature annealing treatment, the sample is only partially dehydrated.
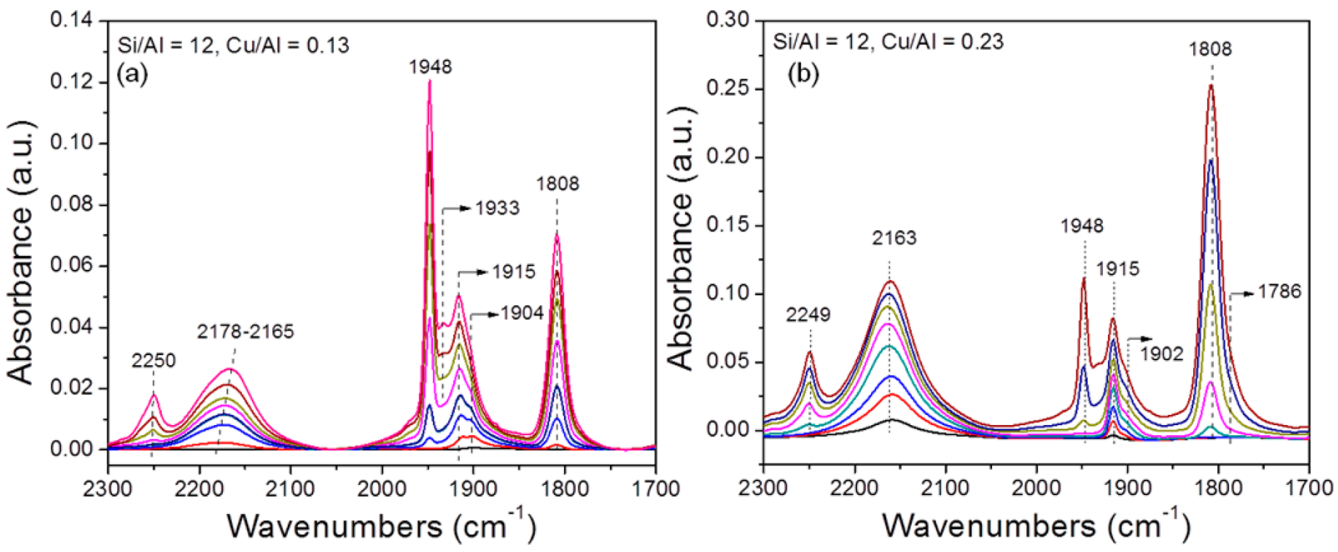

Figure 12. (a) Series of selected IR spectra obtained after exposure of a $\mathrm{Cu} / \mathrm{SSZ}-13$ sample $(\mathrm{Si} / \mathrm{Al}=12, \mathrm{Cu} / \mathrm{Al}=0.13)$ to $\mathrm{NO} 300 \mathrm{~K}$. The sample was annealed in vacuum at $773 \mathrm{~K}$ for $2 \mathrm{~h}$ prior to IR measurements. (b) Series of selected IR spectra obtained after exposure of a Cu/SSZ-13 sample $(\mathrm{Si} / \mathrm{Al}=12, \mathrm{Cu} / \mathrm{Al}=0.23)$ to $\mathrm{NO} 300 \mathrm{~K}$. The sample was annealed in vacuum at $773 \mathrm{~K}$ for $2 \mathrm{~h}$ prior to IR measurements.
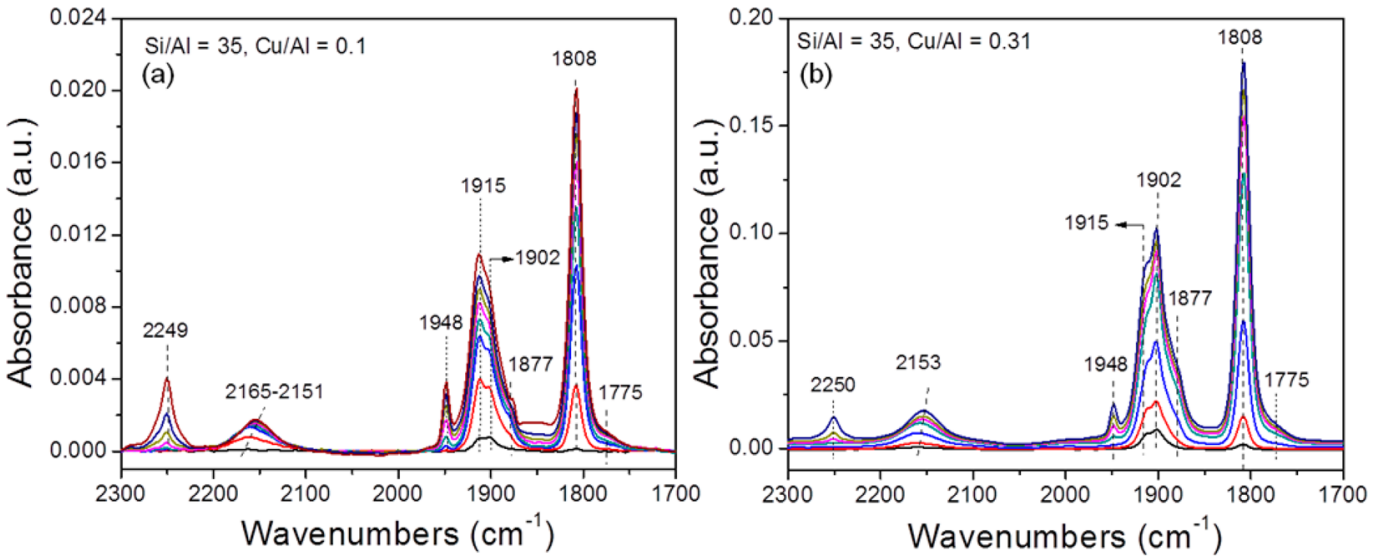

Figure 13. (a) Series of selected IR spectra obtained after exposure of a $\mathrm{Cu} / \mathrm{SSZ}-13$ sample $(\mathrm{Si} / \mathrm{Al}=35, \mathrm{Cu} / \mathrm{Al}=0.10)$ to $\mathrm{NO} 300 \mathrm{~K}$. The sample was annealed in vacuum at $773 \mathrm{~K}$ for $2 \mathrm{~h}$ prior to IR measurements. (b) Series of selected IR spectra obtained after exposure of a Cu/SSZ-13 sample $(\mathrm{Si} / \mathrm{Al}=35, \mathrm{Cu} / \mathrm{Al}=0.31)$ to $\mathrm{NO} 300 \mathrm{~K}$. The sample was annealed in vacuum at $773 \mathrm{~K}$ for $2 \mathrm{~h}$ prior to IR measurements.

$\mathrm{cm}^{-1}$, slightly red-shifted as compared with the higher $\mathrm{Cu}$ loading sample. Also, the $\sim 1930 \mathrm{~cm}^{-1}$ feature appears to be much better resolved on this low-Cu loaded sample at high NO pressures. Figure $11 \mathrm{~b}$ presents ambient temperature NO IR spectra collected on the same sample but only annealed in vacuum to $150{ }^{\circ} \mathrm{C}$ prior to $\mathrm{NO}$ adsorption. Note that following such a treatment, the sample is still partially hydrated. ${ }^{10}$ Interestingly, IR spectra are markedly different in this case, and 
key observations are the following: (1) the $1808 \mathrm{~cm}^{-1}$ is very weak, suggesting $\mathrm{Cu}^{2+}$ autoreduction to $\mathrm{Cu}^{+}$essentially does not occur; (2) the $1883 \mathrm{~cm}^{-1}$ band red-shifts slightly to 1876 $\mathrm{cm}^{-1}$ at low NO pressures while, with increasing NO pressure, a new and strong $\mathrm{Cu}^{2+}-\mathrm{NO}$ band develops at $1904 \mathrm{~cm}^{-1}$; and (3) the relative intensity for the $1948 \mathrm{~cm}^{-1}$ feature, as compared to other $\mathrm{Cu}^{2+}-\mathrm{NO}$ bands at lower frequencies, is much weaker. Meanwhile, the $\sim 1930 \mathrm{~cm}^{-1}$ band cannot be resolved.

Figure 12 presents ambient temperature NO IR spectra collected on $\mathrm{Cu} / \mathrm{SSZ}-13$ samples $(\mathrm{Si} / \mathrm{Al}=12, \mathrm{Cu} / \mathrm{Al}=0.13$ (a) and $\mathrm{Cu} / \mathrm{Al}=0.23(\mathrm{~b}))$ annealed in vacuum at $500{ }^{\circ} \mathrm{C}$ prior to $\mathrm{NO}$ adsorption. For both samples, $\mathrm{Cu}^{2+}-\mathrm{NO}$ bands at $\sim 1902$ and $1915 \mathrm{~cm}^{-1}$ develop first, and with increasing NO pressure, a strong band at $1948 \mathrm{~cm}^{-1}$ grows. The $\sim 1930 \mathrm{~cm}^{-1}$ feature only becomes reasonably well-defined at the highest $\mathrm{NO}$ pressures. Note that the relative signal intensities change as a function of $\mathrm{Cu} / \mathrm{Al}$ ratios. Specifically, the $\mathrm{Cu}^{+}-\mathrm{NO}$ band at $1808 \mathrm{~cm}^{-1}$ becomes much stronger than $\mathrm{Cu}^{2+}-\mathrm{NO}$ bands at $\mathrm{Cu} / \mathrm{Al}=0.23$, suggesting that the extent of autoreduction is enhanced as $\mathrm{Cu}$ loading increases. It is also clear that the relative signal intensity for $\mathrm{N}_{2} \mathrm{O}\left(\right.$ at $\left.\sim 2250 \mathrm{~cm}^{-1}\right)$ is higher for the $\mathrm{Si} / \mathrm{Al}=12$ samples as compared to the $\mathrm{Si} / \mathrm{Al}=6$ ones shown in Figures 10 and 11.

Finally, Figure 13 depicts NO adsorption IR spectra acquired on $\mathrm{Cu} / \mathrm{SSZ}-13$ samples $(\mathrm{Si} / \mathrm{Al}=35, \mathrm{Cu} / \mathrm{Al}=0.1$ (a) and $\mathrm{Cu} /$ $\mathrm{Al}=0.31(\mathrm{~b}))$ annealed in vacuum at $500{ }^{\circ} \mathrm{C}$ prior to $\mathrm{NO}$ adsorption at ambient temperature. For both samples, vibrational bands at $2165,1915,1902$, and $1808 \mathrm{~cm}^{-1}$ appear immediately after the first NO dose. With increasing NO pressure, an $\mathrm{N}_{2} \mathrm{O}$ band at $\sim 2250 \mathrm{~cm}^{-1}, \mathrm{Cu}^{2+}-\mathrm{NO}$ bands at 1948 and $1877 \mathrm{~cm}^{-1}$, and a $\mathrm{Cu}^{+}-\mathrm{NO}$ band at $1775 \mathrm{~cm}^{-1}$ start to develop. Three key findings are worth pointing out for these two samples: (1) markedly different from samples with lower $\mathrm{Si} / \mathrm{Al}$ ratios, the $1948 \mathrm{~cm}^{-1}$ feature appears to be much weaker as compared to other $\mathrm{Cu}^{2+}-\mathrm{NO}$ bands (between 1880 and $\left.1915 \mathrm{~cm}^{-1}\right)$; (2) the $\mathrm{Cu}^{+}-\mathrm{NO}$ band at $1808 \mathrm{~cm}^{-1}$ is very strong, indicating facile $\mathrm{Cu}^{2+}$ autoreduction to $\mathrm{Cu}^{+}$for these samples; and (3) the intensity for the $\mathrm{N}_{2} \mathrm{O}$ band at $\sim 2250 \mathrm{~cm}^{-1}$ becomes comparable to the $\mathrm{NO}^{+}$feature at $\sim 2160 \mathrm{~cm}^{-1}$ for these two samples. In contrast, for lower $\mathrm{Si} / \mathrm{Al}$ samples, the intensity for the $\mathrm{N}_{2} \mathrm{O}$ band is generally somewhat to considerably weaker than $\mathrm{NO}^{+}$.

\section{DISCUSSION}

One of the key attributes of $\mathrm{Cu} / \mathrm{SSZ}-13$ is its structural simplicity; the CHA structure is constructed by stacking double $6 \mathrm{MRs}$ so that all tetrahedral sites ( $\mathrm{T}$-sites, $\mathrm{Al}$ and $\mathrm{Si}$ ) are in equivalent structural positions. $\mathrm{Cu}$ ions have been initially suggested to be present only as isolated monomers $\left(\mathrm{Cu}^{2+}\right.$ and $\left.\mathrm{Cu}^{+}\right)$, and that they solely occupy one extra-frame site, that is, faces of $6 \mathrm{MRs}^{5}{ }^{5}$ In view of this evident structural simplicity, we ${ }^{3}$ and others ${ }^{4,5}$ have suggested that $\mathrm{Cu} / \mathrm{SSZ}-13$ offers an excellent opportunity to elucidate some long-standing questions regarding $\mathrm{NH}_{3}-\mathrm{SCR}$, including the nature of the catalytically active centers and detailed reaction mechanism(s). With continuing research efforts, however, it has become evident that the situation is significantly more complicated than initially thought. First, it is an oversimplification to suggest one type and one location for the catalytic centers within $\mathrm{Cu} / \mathrm{SSZ}$ 13. ${ }^{8,13,31}$ In line with studies on other $\mathrm{Cu} /$ zeolite SCR catalysts, the nature and location of $\mathrm{Cu}$ species are influenced by multiple factors including structure of the zeolites, $\mathrm{Si} / \mathrm{Al}$ ratios, $\mathrm{Cu}$ loadings, and synthesis methods. ${ }^{4,36,40}$ Second, oxidation states, locations, and chemical nature of the $\mathrm{Cu}$ catalytic centers are expected to vary as a function of reaction conditions; therefore, only in operando spectroscopic techniques applicable to $\mathrm{NH}_{3}-$ SCR are, in principle, able to accurately monitor these dynamic variations allowing the establishment of accurate structurefunction relationships. Although great progress has been reported in studies of these materials under in operando conditions, ${ }^{9,10}$ using probe molecules to identify the location and characterize the nature of catalytically relevant $\mathrm{Cu}$ species is clearly an important component to achieve this goal.

In our previous study, ${ }^{32}$ using ${ }^{14} \mathrm{NO}$ and ${ }^{15} \mathrm{NO}$ as probe molecules, on samples with vacuum annealing, oxidization and reduction treatments, as well as with and without the presence of moisture, we were able to gain detailed information on the nature of various isolated ionic $\mathrm{Cu}$ species. For example, we divided $\mathrm{Cu}^{2+}-\mathrm{NO}$ bands into two groups based on their relative stabilities in our previous study, and denoted the less stable $\mathrm{Cu}^{2+}-\mathrm{NO}$ species (giving rise to the 1948 and 1932 $\mathrm{cm}^{-1}$ bands) to $\mathrm{Cu}^{2+} \ldots \mathrm{NO}$ (II) and the more stable $\mathrm{Cu}^{2+}-\mathrm{NO}$ species (giving rise to bands from 1870 to $1915 \mathrm{~cm}^{-1}$ ) to $\mathrm{Cu}^{2+} \ldots \mathrm{NO}(\mathrm{I})$. We also realized that in the presence of moisture, $\mathrm{Cu}^{2+} \ldots \mathrm{NO}$ (II) partially converts to $\mathrm{Cu}^{2+} \ldots \mathrm{NO}(\mathrm{I})$. However, we were unable to give more detailed assignments in our previous study. In the present work, with experimental aid from samples with various $\mathrm{Si} / \mathrm{Al}$ and $\mathrm{Cu} / \mathrm{Al}$ ratios (Figures 11-13) and new information from DFT calculations, detailed assignments of most of the FTIR spectral features are achieved, as will be discussed below.

$\mathrm{Cu}^{2+}-\mathrm{NO}$ species that gives rise to the $1948 \mathrm{~cm}^{-1}$ band are discussed first. Note that this band is very sharp (fwhm $<10$ $\mathrm{cm}^{-1}$ ), suggesting that (1) relevant $\mathrm{Cu}^{2+}$ ions occupy a highly specified charge balancing site and that (2) no other chemisorbed species are in close vicinity to perturb NO vibrations. It is also clear that, on samples with lower $\mathrm{Si} / \mathrm{Al}$ ratios (6 and 12, Figures 10-12), this band is the dominant $\mathrm{Cu}^{2+}-\mathrm{NO}$ species at high NO pressures, while for the sample with a $\mathrm{Si} / \mathrm{Al}$ ratio of 35 , the relative intensity of this band diminishes dramatically (Figure 13). From the DFT results shown in Figure 3, good agreement is found for the $\mathrm{Z}_{2} \mathrm{Cu}-\mathrm{NO}$ species with our experimental results. Therefore, it is quite certain that the $1948 \mathrm{~cm}^{-1}$ band is due to NO adsorbed on $\mathrm{Cu}^{2+}$ sites in the faces of the $6 \mathrm{MR}$. The $1932 \mathrm{~cm}^{-1}$ band is also likely $\mathrm{NO}$ adsorbed on $\mathrm{Cu}^{2+}$ sites in the faces of $6 \mathrm{MR}$, but with an energetically less favorable structure (see Figure S2 in Supporting Information); that is, two $\mathrm{Al} \mathrm{T}$ sites are separated by one $\mathrm{Si} \mathrm{T}$ site instead of two, as shown in Figure $3 \mathrm{~b}$.

$\mathrm{Next}, \mathrm{Cu}^{2+}-\mathrm{NO}$ species giving rise to bands from 1870 to $1915 \mathrm{~cm}^{-1}$ are discussed. Note first that these bands develop prior to the $1948 / 1932 \mathrm{~cm}^{-1}$ bands during $\mathrm{NO}$ adsorption and maintain longer during evacuation. Note also that we discovered previously that the relative intensities of these bands are enhanced in the presence of moisture at the expense of the $1948 / 1932 \mathrm{~cm}^{-1}$ features. In the present study, on the partially dehydrated $\mathrm{Si} / \mathrm{Al}=6$ sample (Figure $11 \mathrm{~b}$ ), these bands also dominate over the $1948 / 1932 \mathrm{~cm}^{-1}$ features. For the $\mathrm{Si} / \mathrm{Al}$ = 35 samples, these bands still dominate even when the samples have been fully dehydrated (annealed in vacuum at $500{ }^{\circ} \mathrm{C}$ ). These experimental findings strongly suggest the following: (1) stronger binding between $\mathrm{Cu}^{2+}$ and $\mathrm{NO}$ for the NO species that give rise to bands from 1870 to $1915 \mathrm{~cm}^{-1}$; (2) these bands are likely associated with $\mathrm{H}_{2} \mathrm{O}$ and/or $-\mathrm{OH}$ ligands. While binding with a $\mathrm{H}_{2} \mathrm{O}$ molecule does not change the oxidation state of a 
copper ion, binding with an $-\mathrm{OH}$ ligand converts $\mathrm{Cu}^{+}$to $\mathrm{Cu}^{2+}$. Interestingly, a $\mathrm{H}_{2} \mathrm{O}$ ligand effectively moderates the energy difference between $\mathrm{Cu}^{+}$ions in the faces of $6 \mathrm{MR}$ and $8 \mathrm{MR}$; an $-\mathrm{OH}$ ligand even makes $8 \mathrm{MR}$ sites energetically much more favorable (Table 2). The calculated NO vibrational frequencies shown in Figure 9, therefore, strongly suggest that the experimental bands from 1870 to $1915 \mathrm{~cm}^{-1}$ can be assigned to $\left[\mathrm{Cu}^{\mathrm{II}}(\mathrm{OH})\right]^{+}-\mathrm{NO}$ species located close to $8 \mathrm{MR}$. The reason why two or three bands overlap in this region can be argued to be caused by the slight differences of local environments in the vicinity of the $\mathrm{Cu}$ ion centers. We note that in previous studies, ${ }^{7} \mathrm{Cu}^{2+}$ ions have been suggested to only occupy faces of $6 \mathrm{MR}$ and they even stay in such positions under SCR reaction conditions. From both DFT calculations and simple chemisorption FTIR experiments, we show in this study that the previous understandings on $\mathrm{Cu}^{2+}$ ion location may need to be revised.

The nature of the $\mathrm{Cu}^{+}-\mathrm{NO}$ species is discussed in this section. As has been well-known, $\mathrm{Cu}^{+}$formation is due to the so-called "autoreduction" which occurs when $\mathrm{Cu}$-ion-exchanged zeolite materials are annealed in vacuum. Therefore, $\mathrm{Cu}^{+}$ formation in this highly idealized condition may not correlate with $\mathrm{Cu}^{+}$formation under standard $\mathrm{NH}_{3}-\mathrm{SCR}$ reaction conditions found by others. For example, the sample used to collect spectra shown in Figure 10 has much higher $\mathrm{Cu}$ content than the sample used to collect data for Figure 11a, yet under the highly idealized NO chemisorption conditions, the resulting spectra are quite similar. Nevertheless, by comparing the 1808 $\mathrm{cm}^{-1}$ bands obtained from samples with various $\mathrm{Si} / \mathrm{Al}$ ratios (Figures 10-13), some interesting and subtle differences are noticed: (1) For the $\mathrm{Si} / \mathrm{Al}=6$ samples, the shoulder band at $\sim 1786 \mathrm{~cm}^{-1}$ is better resolved than for samples with higher $\mathrm{Si} /$ $\mathrm{Al}$ ratios. (2) The full width at half-maximums (fwhms) of the $1808 \mathrm{~cm}^{-1}$ band for samples with different $\mathrm{Si} / \mathrm{Al}$ ratios are very different. At high NO pressures, the fwhms are $\sim 32, \sim 22$, and $\sim 15 \mathrm{~cm}^{-1}$, for samples with $\mathrm{Si} / \mathrm{Al}$ ratios of 6,12 and 35 , respectively. This finding indicates that the $1808 \mathrm{~cm}^{-1}$ band should not be assigned to a single $\mathrm{Cu}^{+}-\mathrm{NO}$ species. From Figures 3 and 6 , the calculated structures giving rise to the 1794,1788 , and $1795 \mathrm{~cm}^{-1}$ bands can all contribute to the experimental $1808 \mathrm{~cm}^{-1}$ band. By changing the $\mathrm{Cu}^{+}$locations, there is a $7 \mathrm{~cm}^{-1}$ shift for the NO frequency in the $\mathrm{Cu}^{+}-\mathrm{NO}$ conformation, which is consistent with that reported in the literature. ${ }^{21}$ Note specifically, with the decrease in $\mathrm{Si} / \mathrm{Al}$ ratios (i.e., the increase in Brønsted acid site density), contribution of the $1808 \mathrm{~cm}^{-1}$ band from $\mathrm{HZ}_{2} \mathrm{Cu}$ is expected to increase. This seems to nicely explain the fwhm increase with decreasing $\mathrm{Si} / \mathrm{Al}$ ratios. For both $\mathrm{Cu}^{2+}-\mathrm{NO}$ and $\mathrm{Cu}^{+}-\mathrm{NO}$ species, there appears to be a systematic $10-20 \mathrm{~cm}^{-1}$ difference between the experimental NO vibrations and their DFT counterparts (the calculated values are smaller). In this sense, we do not have a good assignment for the experimental shoulder band at $\sim 1786$ $\mathrm{cm}^{-1}$.

Finally, the experimental $\mathrm{NO}^{+}$bands (at $\sim 2160 \mathrm{~cm}^{-1}$ ) and the $\mathrm{N}_{2} \mathrm{O}$ species (at $\sim 2250 \mathrm{~cm}^{-1}$ ) are briefly discussed. There have been some historic debates on the nature of the NO vibrational band at $\sim 2130-2170 \mathrm{~cm}^{-1}$. Work done by Hadjiivanov et. $\mathrm{al}^{41}$ appeared to settle the argument, and this band on a bare zeolite is now generally agreed to be a $\mathrm{NO}^{+}$ species adsorbed on extra framework cationic sites. In a recent publication, we assigned this band on $\mathrm{Cu} / \mathrm{SSZ}-13$ to a $\mathrm{NO}^{+}$ species as well. ${ }^{13}$ Moreover, our in situ solid state NMR results strongly suggest that this band directly associates with $\mathrm{Cu}$ ions.
Accordingly, we assigned this $\mathrm{NO}$ species to a $\mathrm{Cu}^{+}-\mathrm{NO}^{+}$ complex formed by charge transfer from $\mathrm{NO}$ to $\mathrm{Cu}^{2+}$. In the present study, from the comparison between Figure 10 and Figure 11a, although the sample used to collect spectra for Figure 10 has a $\mathrm{Cu}$ loading more than 10 times higher than that used to collect spectra for Figure 11a, the relative $\mathrm{NO}^{+}$band signal intensities (as compared to the $\mathrm{Cu}^{2+}-\mathrm{NO}$ and $\mathrm{Cu}^{+}-\mathrm{NO}$ bands) are quite similar. Moreover, from Figures 11-13, as the $\mathrm{Si} / \mathrm{Al}$ ratios increase (i.e., Brønsted acid site density decreases), the general trend is that the relative $\mathrm{NO}^{+}$band signal intensities decrease. This is especially obvious for the $\mathrm{Si} / \mathrm{Al}=35$ samples. Therefore, the $\mathrm{NO}^{+}$species do not appear to adsorb directly on $\mathrm{Cu}$ ion sites, but rather, they occupy cationic positions that compensate framework negative charges. However, they must be in close proximity to the $\mathrm{Cu}$ ions in order to allow for the interactions observed with our prior in situ NMR experiments. ${ }^{13}$ Although DFT calculations in either case could not match the experimental NO vibrational frequencies for this species, the effect of partial charge on the frequency of NO in the gas phase was studied to support this assignment. As shown in Figure S3 of the Supporting Information, the frequency of $\mathrm{NO}$ increases as the charge on $\mathrm{NO}$ increases from negative to positive values. Similar predictions on the $\mathrm{CO}$ vibrational frequencies were reported to follow the trend $\mathrm{CuCO}<$ $(\mathrm{CuCO})^{+}<(\mathrm{CuCO})^{2+}$ by using a cluster model. ${ }^{15}$ Positive charge of NO means loss of electron density from NO. In this sense, the $\sim 2160 \mathrm{~cm}^{-1}$ bands is produced by electron transfer from $\mathrm{NO}$ to a site in $\mathrm{Cu} / \mathrm{SSZ}-13$ where $\mathrm{NO}$ adsorbed. Thus, the assignment of $\mathrm{NO}^{+}$at $\sim 2160 \mathrm{~cm}^{-1}$ bands is reasonable, although the corresponding conformation associated with this $\mathrm{NO}^{+}$species remains unclear.

Finally we comment on the $\mathrm{N}_{2} \mathrm{O}$ band centered at $\sim 2250$ $\mathrm{cm}^{-1}$. As shown in Figures 10-13, this band's position is independent of the samples, which have different ratios of $\mathrm{Si} / \mathrm{Al}$ and $\mathrm{Cu} / \mathrm{Al}$. This result is supported by the DFT calculations. As shown in Figure $\mathrm{S} 4$ in Supporting Information, the frequencies of $\mathrm{N}-\mathrm{O}$ in $\mathrm{N}_{2} \mathrm{O}$ adsorbed on $\mathrm{ZCu}, \mathrm{Z}_{2} \mathrm{Cu}$, and $\mathrm{HZ}_{2} \mathrm{Cu}$, which are 2367,2339 , and $2362 \mathrm{~cm}^{-1}$, have only slight variations. These results are also quite similar to a cluster model estimate of $2360 \mathrm{~cm}^{-1} \cdot{ }^{17}$ It is concluded that the frequency of $\mathrm{N}-\mathrm{O}$ in $\mathrm{N}_{2} \mathrm{O}$ is largely independent of the chemical environment of $\mathrm{Cu}$ in $\mathrm{Cu} / \mathrm{SSZ}-13$. Under $\mathrm{NH}_{3}-\mathrm{SCR}$ reaction conditions, $\mathrm{N}_{2} \mathrm{O}$ is typically undetectable on freshly prepared $\mathrm{Cu}-\mathrm{SSZ}-13$ catalysts at relatively low $\mathrm{Cu}$ loadings. Over high $\mathrm{Cu}$ loading fresh catalysts, it does form (although yields are typically very low) from $\mathrm{NH}_{4} \mathrm{NO}_{3}$ decomposition. On hydrothermally aged catalysts, $\mathrm{N}_{2} \mathrm{O}$ formation is greatly enhanced above $\sim 400{ }^{\circ} \mathrm{C}$; its formation in this case is believed to be catalyzed by $\mathrm{CuO}_{x}$ clusters formed during catalyst aging. In the present study, $\mathrm{N}_{2} \mathrm{O}$ formation may originate from $\mathrm{NO}$ disproportionation or $\mathrm{NO}$ reduction by $\mathrm{Cu}$ ions. Again, under such highly idealized experimental conditions, one cannot correlate $\mathrm{N}_{2} \mathrm{O}$ formation here with that observed during $\mathrm{NH}_{3}-$ SCR reactions.

\section{CONCLUSIONS}

By varying $\mathrm{Si} / \mathrm{Al}$ and $\mathrm{Cu} / \mathrm{Al}$ ratios, $\mathrm{Cu} / \mathrm{SSZ}-13$ samples with different $\mathrm{Cu}$ ion extra-framework locations are obtained. For samples fully dehydrated in high vacuum, three chemisorbed $\mathrm{NO}$ species coexist upon $\mathrm{NO}$ adsorption. These are $\mathrm{NO}^{+}$ species $\left(\sim 2170-2160 \mathrm{~cm}^{-1}\right), \mathrm{Cu}^{2+}-\mathrm{NO}$ species $(1950-1850$ $\left.\mathrm{cm}^{-1}\right)$, and $\mathrm{Cu}^{+}-\mathrm{NO}$ species $\left(1808-1770 \mathrm{~cm}^{-1}\right)$. The relative signal intensities for these bands vary significantly with 
changing $\mathrm{Si} / \mathrm{Al}$ ratios. With the aid of DFT calculations, the species responsible for these vibrations can be assigned in detail. Table 4 summarizes the assignments by comparing

Table 4. Main Findings from the Experimental and Theoretical Results of NO Frequencies $\left(\mathrm{cm}^{-1}\right)$ in Different Configurations

$\begin{array}{lcc}\text { NO frequency }\left(\mathrm{cm}^{-1}\right) & \text { experimental results } & \text { computational results } \\ \mathrm{Cu}^{2+}-\mathrm{NO} & 1850-1950 & 1895-1932 \\ {[\mathrm{Cu}(\mathrm{II}) \mathrm{OH}]^{+}-\mathrm{NO}} & 1870-1915 & 1874,1907 \\ \mathrm{Cu}^{+}-\mathrm{NO} & 1770-1808 & 1794,1788,1795 \\ \mathrm{Cu}-\mathrm{N}_{2} \mathrm{O} & \sim 2250 & 2367,2339,2362 \\ \mathrm{Cu}^{+}-\mathrm{NO}^{+} & 2160-2170 & -\end{array}$

experimental and computational results. DFT results show that $\mathrm{Cu}$ ions are 3-fold and 4-fold coordinated to lattice $\mathrm{O}$ atoms and present in +1 and +2 oxidation states for $\mathrm{ZCu}$ and $\mathrm{Z}_{2} \mathrm{Cu}$, respectively. In addition, the calculated stretching vibrational frequencies for $\mathrm{Cu}^{2+}-\mathrm{NO}$ and $\mathrm{Cu}^{+}-\mathrm{NO}$ are 1929 and 1794 $\mathrm{cm}^{-1}$, respectively. Furthermore, $\mathrm{Cu}^{+}$ions are shown to be substantially stabilized by $-\mathrm{OH}$ ligands $\left(\right.$ as $\left.\left[\mathrm{Cu}^{\mathrm{II}}(\mathrm{OH})\right]^{+}\right)$, making extra-framework sites in $8 \mathrm{MR}$ energetically more favorable than $6 \mathrm{MR}$ sites (the energetically more favorable sites for "naked" $\mathrm{Cu}^{2+}$ ions). FTIR results coupled with DFT calculations allow us to conclude that $\mathrm{NO}$ molecules do bind stronger on $\left[\mathrm{Cu}^{\mathrm{II}}(\mathrm{OH})\right]^{+}$located in $8 \mathrm{MR}$ than naked $\mathrm{Cu}^{2+}$ ions in the $6 \mathrm{MR}$. This new knowledge that $\mathrm{Cu}^{2+}$ ions are indeed stabilized with ligands in $8 \mathrm{MR}$ sites should greatly aid our understanding in $\mathrm{Cu} / \mathrm{CHA}$ SCR catalysts.

\section{ASSOCIATED CONTENT}

\section{S Supporting Information}

Plots of energy as a function of volume, local structures, energy differences and bond lengths, locations of the Brønsted acid site, comparisons between HSE06 and PW91 functionals, total and adsorption energies, charge effect on the frequency of NO in gas phase. This material is available free of charge via the Internet at http://pubs.acs.org.

\section{AUTHOR INFORMATION}

\section{Corresponding Authors}

*E-mail: js.mcewen@wsu.edu.

*E-mail: chuck.peden@pnnl.gov.

\section{Notes}

The authors declare no competing financial interest.

\section{ACKNOWLEDGMENTS}

For the authors from Washington State University, this work was supported by institutional funds provided to J.-S.M. from the Voiland School of Chemical Engineering and Bioengineering. This work was partially funded by USDA/NIFA through Hatch Project \#WNP00807 titled: "Fundamental and Applied Chemical and Biological Catalysts to Minimize Climate Change, Create a Sustainable Energy Future, and Provide a Safer Food Supply". For those of us from Pacific Northwest National Laboratory (PNNL), financial support was provided by the U.S. Department of Energy (DOE), Office of Energy Efficiency and Renewable Energy, Vehicle Technologies Program. A portion of the research (including both computer time for DFT and experimental FTIR work) was performed using EMSL, a national scientific user facility sponsored by the Department of Energy's Office of Biological and Environmental
Research and located at PNNL. PNNL is a multiprogram national laboratory operated for the U.S. DOE by Battelle. We also thank Ms. Kathy Helling for her useful comments on the manuscript.

\section{REFERENCES}

(1) Bull, I.; Xue, W. M.; Burk, P.; Boorse, R. S.; Jaglowski, W. M.; Koermer, G. S.; Moini, A.; Patchett, J. A.; Dettling, J. C.; Caudle, M. T. Copper CHA zeolite catalysts. Patent no. US7601662 B2, 2009.

(2) Andersen, J.; Bailie, J. E.; Casci, J. L.; Chen, H.-Y.; Fedeyko, J. M.; Foo, R. K. S.; Rajaram, R. R. Transition metal/zeolite SCR catalysts. Patent no. WO/2008/132452, 2008.

(3) Gao, F.; Kwak, J.; Szanyi, J.; Peden, C. F. Top. Catal. 2013, 56, $1441-1459$.

(4) Deka, U.; Lezcano-Gonzalez, I.; Weckhuysen, B. M.; Beale, A. M. ACS Catal. 2013, 3, 413-427.

(5) Fickel, D. W.; Lobo, R. F. J. Phys. Chem. C 2010, 114, 16331640.

(6) Korhonen, S. T.; Fickel, D. W.; Lobo, R. F.; Weckhuysen, B. M.; Beale, A. M. Chem. Commun. 2011, 47, 800-802.

(7) Deka, U.; Juhin, A.; Eilertsen, E. A.; Emerich, H.; Green, M. A.; Korhonen, S. T.; Weckhuysen, B. M.; Beale, A. M. J. Phys. Chem. C 2012, 116, 4809-4818.

(8) Hun Kwak, J.; Zhu, H.; Lee, J. H.; Peden, C. H. F.; Szanyi, J. Chem. Commun. 2012, 48, 4758-4760.

(9) Gao, F.; Walter, E. D.; Kollar, M.; Wang, Y.; Szanyi, J.; Peden, C. H. F. J. Catal. 2014, 319, 1-14.

(10) Kwak, J. H.; Varga, T.; Peden, C. H. F.; Gao, F.; Hanson, J. C.; Szanyi, J. J. Catal. 2014, 314, 83-93.

(11) Kispersky, V. F.; Kropf, A. J.; Ribeiro, F. H.; Miller, J. T. Phys. Chem. Chem. Phys. 2012, 14, 2229-2238.

(12) McEwen, J. S.; Anggara, T.; Schneider, W. F.; Kispersky, V. F.; Miller, J. T.; Delgass, W. N.; Ribeiro, F. H. Catal. Today 2012, 184, 129-144.

(13) Kwak, J. H.; Lee, J. H.; Burton, S. D.; Lipton, A. S.; Peden, C. H. F.; Szanyi, J. Angew. Chem., Int. Ed. 2013, 52, 9985-9989.

(14) Yang, X.; Wu, Z.; Moses-Debusk, M.; Mullins, D. R.; Mahurin, S. M.; Geiger, R. A.; Kidder, M.; Narula, C. K. J. Phys. Chem. C 2012, 116, 23322-23331.

(15) Schneider, W. F.; Hass, K. C.; Ramprasad, R.; Adams, J. B. J. Phys. Chem. 1996, 100, 6032-6046.

(16) Schneider, W. F.; Hass, K. C.; Ramprasad, R.; Adams, J. B. J. Phys. Chem. B 1997, 101, 4353-4357.

(17) Schneider, W. F.; Hass, K. C.; Ramprasad, R; Adams, J. B. J. Phys. Chem. B 1998, 102, 3692-3705.

(18) C. Hass, K.; F. Schneider, W. Phys. Chem. Chem. Phys. 1999, 1, 639-648.

(19) Göltl, F.; Hafner, J. J. Chem. Phys. 2012, 136, 064501.

(20) Göltl, F.; Hafner, J. J. Chem. Phys. 2012, 136, 064502.

(21) Göltl, F.; Hafner, J. J. Chem. Phys. 2012, 136, 064503.

(22) Bates, S. A.; Verma, A. A.; Paolucci, C.; Parekh, A. A.; Anggara, T.; Yezerets, A.; Schneider, W. F.; Miller, J. T.; Delgass, W. N.; Ribeiro, F. H. J. Catal. 2014, 312, 87-97.

(23) Verma, A. A.; Bates, S. A.; Anggara, T.; Paolucci, C.; Parekh, A. A.; Kamasamudram, K.; Yezerets, A.; Miller, J. T.; Delgass, W. N.; Schneider, W. F.; Ribeiro, F. H. J. Catal. 2014, 312, 179-190.

(24) Göltl, F.; Bulo, R. E.; Hafner, J.; Sautet, P. J. Phys. Chem. Lett. 2013, 4, 2244-2249.

(25) Lezcano-Gonzalez, I.; Deka, U.; Arstad, B.; Van Yperen-De Deyne, A.; Hemelsoet, K.; Waroquier, M.; Van Speybroeck, V.; Weckhuysen, B. M.; Beale, A. M. Phys. Chem. Chem. Phys. 2014, 16, $1639-1650$

(26) Kresse, G.; Furthmüller, J. Phys. Rev. B 1996, 54, 11169.

(27) Kresse, G.; Hafner, J. Phys. Rev. B 1993, 47, 558.

(28) Blöchl, P. E. Phys. Rev. B 1994, 50, 17953.

(29) Kresse, G.; Joubert, D. Phys. Rev. B 1999, 59, 1758-1775.

(30) Perdew, J. P.; Wang, Y. Phys. Rev. B 1992, 45, 13244. 
(31) Gao, F.; Walter, E. D.; Karp, E. M.; Luo, J.; Tonkyn, R. G.; Kwak, J. H.; Szanyi, J.; Peden, C. H. F. J. Catal. 2013, 300, 20-29.

(32) Szanyi, J.; Kwak, J. H.; Zhu, H.; Peden, C. H. F. Phys. Chem. Chem. Phys. 2013, 15, 2368-2380.

(33) Zhang, R.; McEwen, J.-S. Thermodynamic stability and ab initio $\mathrm{X}$-ray absorption modeling of Cu-SSZ-13: Influence of reactants, intermediates, and products in the SCR of $\mathrm{NO}_{x}$. 2014, in preparation.

(34) Suzuki, K.; Sastre, G.; Katada, N.; Niwa, M. Phys. Chem. Chem. Phys. 2007, 9, 5980-5987.

(35) Krukau, A. V.; Vydrov, O. A.; Izmaylov, A. F.; Scuseria, G. E. J. Chem. Phys. 2006, 125, 224106.

(36) Brandenberger, S.; Kröcher, O.; Tissler, A.; Althoff, R. Catal. Rev. 2008, 50, 492-531.

(37) Rice, M. J.; Chakraborty, A. K.; Bell, A. T. J. Catal. 1999, 186, $222-227$.

(38) Goodman, B. R.; Hass, K. C.; Schneider, W. F.; Adams, J. B. Catal. Lett. 2000, 68, 85-93.

(39) Giordanino, F.; Vennestrom, P. N. R.; Lundegaard, L. F.; Stappen, F. N.; Mossin, S.; Beato, P.; Bordiga, S.; Lamberti, C. Dalton Trans. 2013, 42, 12741-12761.

(40) Centi, G.; Perathoner, S. Appl. Catal., A 1995, 132, 179-259.

(41) Hadjiivanov, K.; Saussey, J.; Freysz, J. L.; Lavalley, J. C. Catal. Lett. 1998, 52, 103-108. 